\title{
Therapeutic Opportunities in Eukaryotic Translation
}

\author{
Jennifer $\mathrm{Chu}^{1}$ and Jerry Pelletier ${ }^{1,2,3}$ \\ ${ }^{1}$ Department of Biochemistry, McGill University, Montreal, Quebec H3G 1Y6, Canada \\ ${ }^{2}$ Department of Oncology, McGill University, Montreal, Quebec H3G 1Y6, Canada \\ ${ }^{3}$ Rosalind and Morris Goodman Cancer Research Center, McGill University, Montreal, Quebec H3G 1Y6, Canada \\ Correspondence: jerry.pelletier@mcgill.ca
}

The ability to block biological processes with selective small molecules provides advantages distinct from most other experimental approaches. These include rapid time to onset, swift reversibility, ability to probe activities in manners that cannot be accessed by genetic means, and the potential to be further developed as therapeutic agents. Small molecule inhibitors can also be used to alter expression and activity without affecting the stoichiometry of interacting partners. These tenets have been especially evident in the field of translation. Small molecule inhibitors were instrumental in enabling investigators to capture short-lived complexes and characterize specific steps of protein synthesis. In addition, several drugs that are the mainstay of modern antimicrobial drug therapy are potent inhibitors of prokaryotic translation. Currently, there is much interest in targeting eukaryotic translation as decades of research have revealed that deregulated protein synthesis in cancer cells represents a targetable vulnerability. In addition to being potential therapeutics, small molecules that manipulate translation have also been shown to influence cognitive processes such as memory. In this review, we focus on small molecule modulators that target the eukaryotic translation initiation apparatus and provide an update on their potential application to the treatment of disease.

\begin{abstract}
A large collection of chemical probes targetAing various steps of prokaryotic and eukaryotic translation has been identified and characterized over the last $\sim 50$ years (Pestka 1977; Vazquez 1979; Pelletier and Peltz 2007; Malina et al. 2012). Early efforts in this endeavor were primed by the realization that prokaryotic and eukaryotic translations differ sufficiently to enable selective targeting, from which emerged some of the most effective antimicrobial therapies (aminoglycosides, tetracyclines, macrolides, chloramphenicol, clindamycin, spectinomycin,
\end{abstract}

streptogramins, lincosamides, oxazolindinones, etc.). In the last 15 years, there has been a resurgence of interest in targeting translation driven by a number of medical needs. One is the multidrug resistance crisis currently facing the field of medical microbiology and prompting an urgent need to identify new antibiotics. Another is the realization that targeting the translation apparatus in parasites, such as malaria, offers a broad therapeutic window (Baragaña et al. 2015). A third is the recognition that translational control is frequently usurped in human can-

Editors: Michael B. Mathews, Nahum Sonenberg, and John W.B. Hershey

Additional Perspectives on Translation Mechanisms and Control available at www.cshperspectives.org

Copyright (C) 2018 Cold Spring Harbor Laboratory Press; all rights reserved; doi: 10.1101/cshperspect.a032995

Cite this article as Cold Spring Harb Perspect Biol 2017;10:a032995 
J. Chu and J. Pelletier

cers and represents a druggable vulnerability (Silvera et al. 2010; Stumpf and Ruggero 2011; Bhat et al. 2015; Pelletier et al. 2015; Chu et al. 2016a). Our goal in this review is to visit ongoing developments aimed at targeting the two main regulatory nodes of eukaryotic translation initiation: the eIF4F-mediated ribosome recruitment step and the modulation of eIF2 activity. eIF4F and eIF2 link translational output to changes in extra- and intracellular cues and are critical actors in maintaining cellular homeostasis. For a detailed review of the roles of eIF4F and eIF2 in translation, the reader is referred to Merrick and Pavitt (2018).

\section{THERAPEUTIC TARGETS IN TRANSLATIONAL CONTROL}

\section{Messenger RNA (mRNA) Activation by elF4F}

Cap-dependent translation is mediated by eIF4F, a heterotrimeric complex comprising eIF4E, eIF4A, and eIF4G, with the essential eIF4E cap-binding protein being rate-limiting for translation (Fig. 1). Under conditions of growth restriction, the bulk of eIF4E is sequestered away from eIF4F into translationally inactive complexes by eIF4E-binding proteins (there are three isoforms), leading to reduced capdependent translation (Pause et al. 1994). The phosphoinositide 3-kinase (PI3K)/mechanistic target of rapamycin (mTOR) pathway is critical to cell growth and survival and responds to a multitude of extra- and intracellular cues. Increased signaling flux leads to elevated $4 \mathrm{E}-\mathrm{BP}$ phosphorylation and dissociation of eIF4E:4EBP complexes. Because 4E-BPs and eIF4G share a common binding site on eIF4E, 4E-BP phosphorylation leads to increased eIF4F complex formation. This results in elevated translation of some mRNAs, several of which have been implicated in tumor onset and maintenance (e.g., c-MYC, cyclins, ornithine decarboxylase [ODC], BCL-2, MCL-1, BCL-X $\mathrm{L}_{\mathrm{L}}$, osteopontin, survivin, vascular endothelial growth factor [VEGF], fibroblast growth factors [FGF]) (Colina et al. 2008; Mills et al. 2008; Petroulakis et al. 2009; Dowling et al. 2010; Bhat et al. 2015; Chu et al. 2016a). There are a number of strategies that have been explored to abrogate eIF4F function, including disruption of the eIF4E: eIF4G association, perturbation of the eIF4E:cap interaction, and inhibition of eIF4A and eIF4G activity (Fig. 1).

In mammals, eIF4E activity is also regulated through phosphorylation of Ser 209 by MNK1

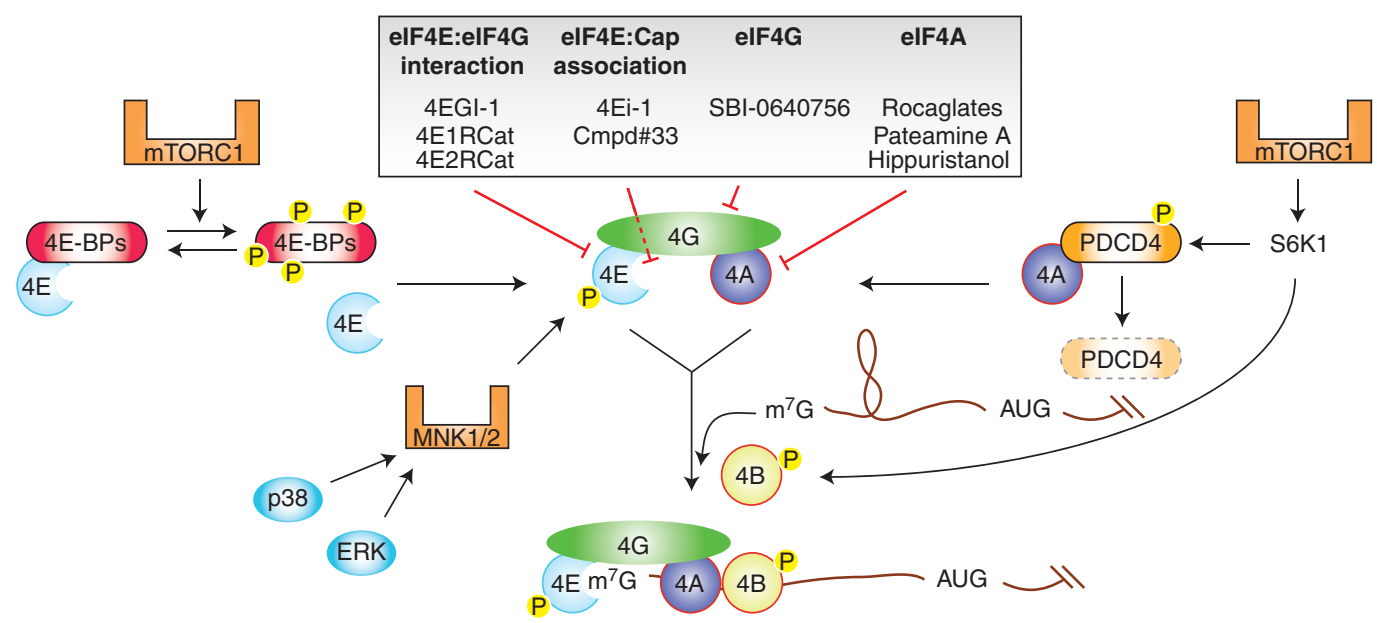

Figure 1. Schematic diagram outlining the regulation of eIF4F assembly by mechanistic target of rapamycin (mTOR), eIF4E phosphorylation by MNK1/2, and messenger (mRNA) recruitment by eIF4F. The targets of known inhibitors are denoted. mTOR complex 1 (mTORC1) is a complex composed of mTOR, Raptor, MLST8, PRAS40, and DEPTOR and links nutrient/redox/energy levels to translation initiation. 
Translating Therapeutics

(mitogen activated protein kinase [MAPK]-interacting kinases) and MNK2, two kinases that function downstream from the p38 MAPK and MEK-ERK (MAPK/ERK kinase-extracellular signal-regulated kinase) signaling cascades (Waskiewicz et al. 1999). In response to stress (p38 MAPK) or mitogens (MEK/ERK) (Cargnello and Roux 2011), the MNKs bind to eIF4G and phosphorylate eIF4E (Pyronnet et al. 1999). This causes preferential translation stimulation of a subset of mRNAs-several of which are known to be required for tumor maintenance (e.g., MCL1, MMP3, SNAIL) (Wendel et al. 2004; Furic et al. 2010; Robichaud et al. 2015).

The association and activity of eIF4A, the helicase subunit of eIF4F, is also affected by mTOR signaling flux through the S6 kinases (S6K1 and S6K2). Activation of S6K1 by mTOR leads to phosphorylation and degradation of programmed cell death 4 (PDCD4), an eIF4Abinding partner that represses translation (Fig. 1) (Yang et al. 2003a). Loss of PDCD4 results in increased eIF4A assembly into the eIF4F complex. S6K also phosphorylates the eIF4A auxiliary factor, eIF4B, which is an RNA-binding protein that promotes initiation complex formation and stimulates eIF4A helicase activity (Raught et al. 2004; Holz et al. 2005).

\section{Ternary Complex Formation}

The second major regulatory checkpoint in translation initiation is ternary complex (TC) formation (Fig. 2). Here, the initiator Met-tRNA $A_{i}^{\text {Met }}$, eIF2, and guanosine triphosphate (GTP) form a TC that is recruited to $40 \mathrm{~S}$ ribosomal subunits. Upon initiation codon recognition, GTP is hydrolyzed and eIF2-guanosine diphosphate (GDP) is released from the ribosome in complex with eIF5. The eIF2B guanine nucleotide exchange factor is required to exchange GDP for GTP as well as to displace eIF5 from eIF2 to enable its participation in subsequent rounds of initiation (Jennings and Pavitt 2014). In response to stress, the eIF $2 \alpha$ subunit is phosphorylated at Ser51 and this increases its affinity for the limiting amounts of eIF2B, leading to sequestration of the latter and reduced eIF2-GDP/eIF2-GTP recycling (Jennings and Pavitt 2014). Decreasing TC availability hinders global translation, while permitting stimulation of translation of a set of mRNAs encoding regulators of the stress response (e.g., GCN4 in yeast, ATF4 in humans), which is an event dependent on appropriately positioned short, upstream open reading frames (ORFs) (see Wek 2018). There are four known kinases that phosphorylate eIF2 $\alpha$ : (1) GCN2

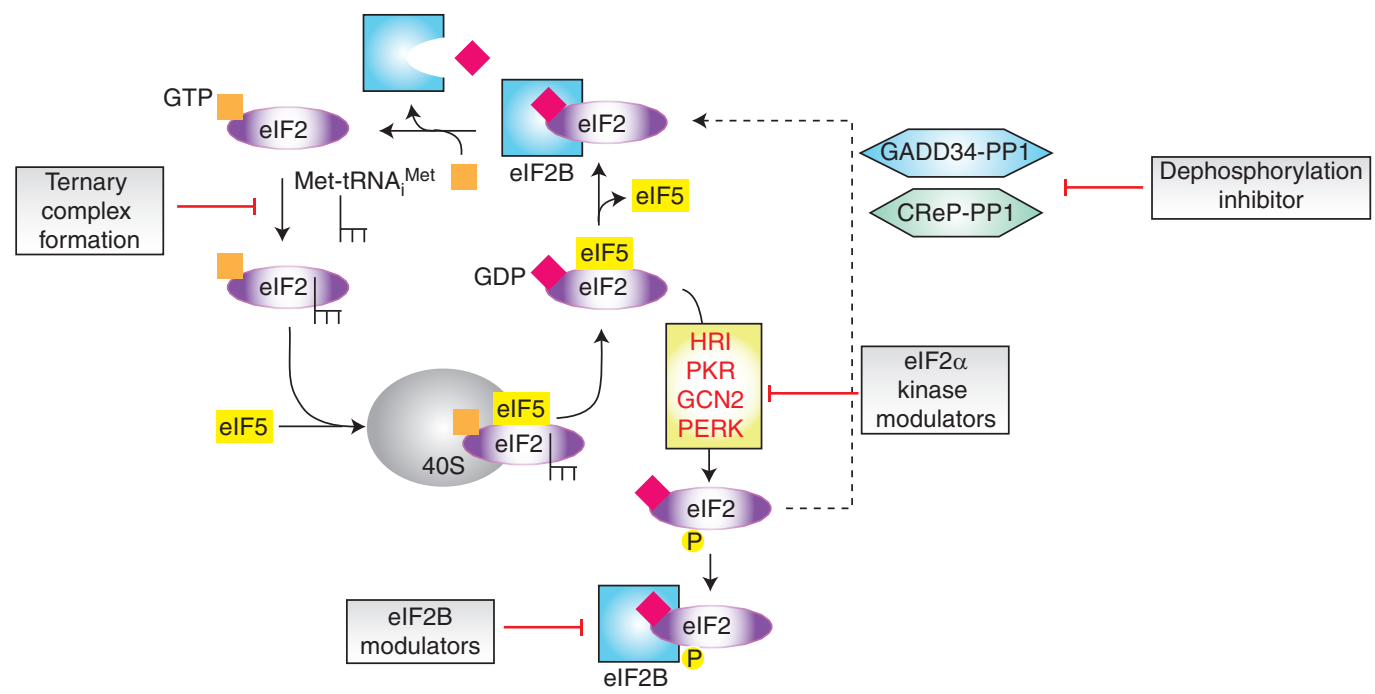

Figure 2. Schematic diagram outlining the regulation of eIF2 recycling and the different steps known to be modulated by small molecules. 
(general control nonderepressible), (2) HRI (heme-regulated inhibitor), (3) PKR (doublestranded RNA-dependent protein kinase), and (4) PERK (PKR-like endoplasmic reticulum kinase). Dephosphorylation of eIF $2 \alpha$ is mediated by protein phosphatase 1 (PP1) containing either GADD34 or CReP (Fig. 2). Small molecules targeting the eIF2 regulatory node have been identified that interfere with TC formation, modulate eIF2 $\alpha$ kinase activity, block dephosphorylation of phospho-eIF2 $\alpha$, and perturb eIF2B activity (Fig. 2).

\section{TRANSLATIONAL CONTROL AND DISEASE}

\section{Cancer}

The discovery that translation is dysregulated in cancer cells emerged from early studies documenting a small $(\sim 6 \%)$ change (increase and decrease) in unique mRNA species associated with polyribosomes from resting compared with growing cells (Williams and Penman 1975; Getz et al. 1976). The subsequent demonstration that eIF4E overexpression could drive tumor initiation (Lazaris-Karatzas et al. 1990) put translational control on the cancer research map and opened a new therapeutic avenue. Subsequent studies highlighted the pervasive extent to which deregulated translation contributes to tumor initiation and maintenance (Robert and Pelletier 2009). First, changes in expression levels and activity of a number of initiation factors have been documented in human cancer cells and tumors, many of which are associated with tumor progression and poor prognosis (Silvera et al. 2010; Chu et al. 2016a). The nonoverlapping nature of the associated changes in mRNA translation suggests a complex layer of gene-expression regulation that remains to be systematically explored. Second, eIF4F activity is often altered by signaling pathways found activated in cancer (PI3K/mTOR, MEK-ERK, p38 MAPK) and this event has been linked to increased cell proliferation and survival (Bhat et al. 2015). Third, the quintessential c-MYC proto-oncogene regulates transcription of the genes encoding eIF2 $\alpha$, eIF4E, eIF4A1, and eIF4G1 (Rosenwald et al. 1993; Lin et al. 2008).
Because c-MYC is a well-characterized eIF4Fresponsive mRNA (Lin et al. 2012; Chu et al. 2016b), this establishes a positive feedback loop. Given that MYC occupies a pinnacle position in the cellular gene expression hierarchy and is among the top amplified genes across all human cancer types (Beroukhim et al. 2010), one would expect the MYC-eIF4F loop to be tightly regulated in normal cells. Fourth, mRNA sequence variations that alter translational efficiency have been associated with tumor initiation or maintenance. These include point mutations in the $5^{\prime}$ leader region of $\mathrm{c}$ MYC, BRCA1, and CDKN2A that affect protein output, as well as usage of alternative splice sites or transcription start sites that lead to significant nucleotide changes in the $5^{\prime}$ leader region $(\mathrm{Me}-$ ric and Hunt 2003). Last, increased eIF4F activity, altered eIF4E/4E-BP1 ratios, and persistent eIF4F complex levels can impart resistance to chemotherapy (e.g., doxorubicin [Wendel et al. 2004], dexamethasone [Robert et al. 2014], cisplatin, and antimitotic microtubule stabilizers [Zhou et al. 2011]) and to therapies targeting the PI3K/mTOR (Mallya et al. 2014) and MAPK pathways (Ilic et al. 2011; Zindy et al. 2011; Alain et al. 2012; Boussemart et al. 2014; Cope et al. 2014; Mallya et al. 2014). Collectively, these studies indicate that changes in translational control can have profound consequences for normal cellular physiology.

A number of in vitro studies have highlighted the value of targeting the eIF4E and eIF4A subunits to curtail tumor cell survival. (1) Early experiments using antisense approaches to suppress eIF4E expression in cell culture showed that this would block the growth of transformed cells, reduce soft agar colonization, increase tumor latency periods in xenograft models, reduce metastatic potential, and enhance chemosensitivity in vitro (Rinker-Schaeffer et al. 1993; Graff et al. 1995; Thumma et al. 2015). (2) Sequestration of eIF4E by ectopic expression of $4 \mathrm{E}-\mathrm{BP} 1$ or by peptides harboring the eIF4E-binding site was shown to inhibit tumor cell proliferation (Rousseau et al. 1996; Herbert et al. 2000) and block eIF4E- and MYC-driven transformation ex vivo and in vivo in xenograft models (Jiang et al. 2003; Lynch et al. 2004). A fusion peptide 
containing the eIF4E-binding site linked to a gonadotropin receptor agonist displayed antineoplastic activity when delivered by intraperitoneal injection to an ovarian xenograft model, with no detectable toxicity (Ko et al. 2009). (3) Antisense suppression of eIF4A or sequestration of eIF4A by ectopic expression of PDCD4 in tumor cells reduced cellular proliferation (Eberle et al. 2002), blocked transformation (Yang et al. 2003b), and delayed tumor onset in a chemically induced murine skin tumor model (Jansen et al. 2005). Delivery of an expression vector driving expression of PDCD4 to $\mathrm{H}$-Ras $12 \mathrm{~V}$ mice with liver cancer significantly reduced tumor burden (Kim et al. 2013).

Manipulating TC availability as an anticancer approach has not been as extensively assessed. One problem is that eIF $2 \alpha$ phosphorylation can have either prosurvival consequences or trigger cell death, depending on context (Bi et al. 2005; Koromilas and Mounir 2013). For example, expression of a nonphosphorylatable eIF2 $\alpha$ mutant (S51A) is capable of transforming NIH 3T3 cells (Donze et al. 1995). Phosphorylation of eIF $2 \alpha$ is observed in response to treatment with different proteasome inhibitors and is associated with an apoptotic response (Jiang and Wek 2005a). However, phosphorylation of eIF2 $\alpha$ in response to ultraviolet (UV) irradiation (mediated by GCN2) facilitates nuclear factor (NF)- $\mathrm{\kappa B}$ activation and leads to a prosurvival response (Jiang and Wek 2005b). Thus, the issue of context has to be better understood to rationalize how best to manipulate this pathway to achieve a proapoptotic response when applied to the treatment of cancer cells.

\section{Cognitive Functions}

eIF2B exists as a dimer of two pentamers of five subunits $(\alpha-\varepsilon)$ (Kashiwagi et al. 2016). The $\alpha, \beta$, and $\delta$ subunits make up the regulatory subcomplex, whereas the $\gamma$ and $\varepsilon$ subunits are responsible for the catalytic activity. Mutations in any of the five eIF2B subunits can lead to a progressive loss of brain white matter known as leukoencephalopathy with vanishing white matter (VWM) or childhood ataxia with central nervous system hypomyelination $(\mathrm{CACH})(\mathrm{Ka}-$ shiwagi et al. 2016). These mutations impact on eIF2B assembly and/or affect eIF2B: eIF2 interactions, both of which diminish TC formation and reduce translational output. This disorder highlights the critical role that eIF2B plays in nervous system development and maintenance.

Perturbing TC formation through modifying eIF2 $\alpha$ phosphorylation status can also affect cognitive function. In eIF2 $2^{+/ S 51 A}$ mice in which eIF $2 \alpha$ phosphorylation is reduced, longterm potentiation and memory are enhanced (Costa-Mattioli et al. 2007). Genetic deletion of PERK or GCN2 in mouse models of Alzheimer's disease $(\mathrm{AD})$ alleviates deficits in protein synthesis, synaptic plasticity, and memory (Ma et al. 2013). Compounds that alter eIF $2 \alpha$ phosphorylation in the brain also impact cognitive functions. Minocycline (a semisynthetic tetracycline) can attenuate eIF2 $\alpha$ phosphorylation in an AD mouse model and this is associated with improved learning and memory (Choi et al. 2007). Trazodone hydrochloride and dibenzoylmethane, two compounds identified for their ability to reverse eIF $2 \alpha$ phosphorylation, can block neurodegeneration, restore memory deficits, and improve survival in prion-disease mice (Halliday et al. 2017). These and additional studies have implicated the eIF2 $\alpha$ kinases in cognitive functions and offer new and exciting avenues to potentially treat neurodegenerative disorders as well as alter cognitive functions (Trinh and Klann 2013).

Dysregulated translation has also been implicated as a core deficit in fragile $\mathrm{X}$ syndrome, with hyperactivation of mTORC1 and MAPK signaling associated with behavioral issues, learning deficits, and developmental delays (Hou et al. 2006; Gkogkas et al. 2014). Remarkably, metformin treatment of $\mathrm{Fmrl}^{-/-}$mice ameliorated the core deficits in this model and this effect was associated with normalization of ERK signaling and reduced eIF4E phosphorylation (Gantois et al. 2017).

\section{IS TARGETING TRANSLATION INITIATION SAFE?}

Targeting translation as an antineoplastic approach is already in the clinic, as exemplified 
by the use of omacetaxine mepesuccinate, a semisynthetic formulation of homoharringtonine (HHT), against tyrosine kinase inhibitorresistant chronic myeloid leukemia (CML). HHT inhibits formation of the first peptide bond (Garreau de Loubresse et al. 2014) and, therefore, is quite different from a targeted therapy in which only one tumor cell dependency is blocked. A significant percent of patients with CML show a major cytogenetic response (i.e., reduction in Philadelphia chromosome-positive cells) when administered omacetaxine mepesuccinate (Alvandi et al. 2014). Several adverse reactions were reported (Alvandi et al. 2014), including some that were considered serious but manageable. HHT will block synthesis of all proteins in transformed and normal cells and the selectivity of HHT for CML versus normal cells likely stems from inhibition of synthesis of short-lived oncoproteins to which tumor cells have become addicted, such as MCL-1 and c-MYC (Chen et al. 2006; Robert et al. 2009a).

Unlike the global inhibitory effects on translation exerted in cells treated with HHT, suppression of eIF4E is expected to lead to a more selective reduction in translation of a subset of mRNAs. The preclinical data to date suggest that partial suppression of eIF4E at the organismal level is well tolerated. In mice engineered to express inducible eIF4E short hairpin RNAs (shRNAs) (sh4E/rtTA) in all tissues, transient eIF4E suppression affected only a subset of normal regenerating cells (e.g., immature/undifferentiated intestinal crypts), but was otherwise well tolerated and the aforementioned effects were rapidly and completely reversible (Lin et al. 2012). Systemic suppression of sh4E/rtTA mice also carrying an E $\mu-\mathrm{Myc}$ translocation significantly delayed B-cell tumor onset (Lin et al. 2012). Similarly, eIF4 $\mathrm{E}^{+/-}$mice showed no developmental defects and had normal body weights and survival (Truitt et al. 2015). When $\mathrm{eIF}^{\mathrm{E}} \mathrm{E}^{+-}$mice were crossed to a KRas ${ }^{\mathrm{G} 12 \mathrm{D}}$ driven lung cancer model, eIF4E $\mathrm{E}^{+/-} / \mathrm{KRas}^{\mathrm{G} 12 \mathrm{D}}$ mice showed reduced tumor burden compared with $\mathrm{eIF} 4 \mathrm{E}^{+/+} / \mathrm{KRas}^{\mathrm{G} 12 \mathrm{D}}$ mice (Truitt et al. 2015). Telling are the consequences of suppressing eIF4E expression systemically using antisense oligonucleotides (ASOs). Here, an eIF4E ASO that targets the $3^{\prime}$ untranslated region (LY2275796; GenBank: M15353, nucleotides 1285-1304) was developed and tested in vivo (Graff et al. 2007). When administered at $50 \mathrm{mg} / \mathrm{kg}$ thrice weekly in an MDA-MB-231 breast cancer xenograft model, a $64 \%$ reduction in eIF4E protein levels was documented in tumors and was associated with a pronounced suppression of tumor outgrowth. At $25 \mathrm{mg} / \mathrm{kg}$ thrice weekly (after an initial loading dose of $50 \mathrm{mg} / \mathrm{kg}$ ) in a PC3 prostate cancer xenograft model, a $56 \%$ reduction in eIF4E protein levels was documented in tumors and was associated with a significant reduction in tumor outgrowth. No change in mean body weight was observed in the MDA-MB231 or PC3 models. Lower concentrations of LY2275796 (5 mg/kg) had no effect on PC3 tumor outgrowth and failed to reduce eIF4E proteins in the tumors. Normal mice dosed with LY2275796 (40 mg/kg twice weekly; $80 \mathrm{mg} / \mathrm{kg} /$ wk) showed an $80 \%$ decrease in eIF4E protein levels in the liver (the site where ASOs preferentially accumulate) with no appreciable change in liver and spleen histology, body weight, or liver transaminase levels detected (Graff et al. 2007).

Two clinical trials with LY2275796 have been undertaken but they failed to satisfactorily address the issue of effectiveness of eIF4E suppression. A phase I trial primarily sought to determine an appropriate delivery dose for LY2275796 in patients (Hong et al. 2011). In this study, LY2275796 was delivered for 3 consecutive days followed by weekly maintenance doses (Hong et al. 2011). The maximum tolerated dose was designated as $1000 \mathrm{mg}$ based on clinical, pharmacokinetic, and pharmacodynamics observations with patients having manageable toxicities (grade 1/2). This dose was reported to cause an $80 \%$ reduction in eIF4E mRNA levels (as determined using a branched DNA assay), but this could not be attributed to a specific effect of LY2275796 because expression of housekeeping genes was also reduced (by $64 \%)$. In pre- and posttreatment biopsy samples, cytoplasmic eIF4E protein levels were assessed by immunohistochemistry and reported to be reduced by $\sim 25 \%$. Cytoplasmic VEGF and nuclear cyclin D1 protein levels (two eIF4F-responsive mRNAs) were unaffected or reduced 
$\sim 25 \%$, respectively. The best response observed was seven patients out of 22 that achieved stable disease for a minimum of 6 weeks. We note that in this study, in which the median patient age was 58.5 years (and based on an average weight of $76 \mathrm{~kg}$ (see shortsupport.org/Research/Papers/ NHANES.pdf), patients received $\sim 52 \mathrm{mg} / \mathrm{kg} / \mathrm{wk}$ (first week) and $13 \mathrm{mg} / \mathrm{kg} / \mathrm{wk}$ (maintenance dose) of LY2275796, which is significantly lower than the doses used to achieve an antitumor response in the aforementioned mouse xenograft studies.

A second clinical trial looked at combining the $4 \mathrm{E}-\mathrm{ASO}$ with irinotecan in solid tumors and irinotecan-refractory colorectal cancer (Duffy et al. 2016). The combination of LY2275796 (1000 mg/wk; $13 \mathrm{mg} / \mathrm{kg} / \mathrm{wk}$ ) and irinotecan was not well tolerated because of chronic lowgrade toxicities (Duffy et al. 2016) and appearance of more severe toxicities (grade 3/4). This likely stemmed from an LY2275796: irinotecan drug interaction that increased the half-life of irinotecan and its metabolites leading to an increased drug exposure. Analysis of post- versus pretreated tumor biopsies found a reduction $(\sim 10 \%-75 \%)$ in eIF4E mRNA levels in $5 / 9$ of patients, but no change in eIF4E protein levels (as assessed by immunohistochemistry). Overall, although the preclinical studies are encouraging, we cannot make general conclusions regarding the effectiveness of suppressing eIF4E and more robust and reliable approaches are needed to inhibit eIF4E/eIF4F activity in the clinical setting.

\section{INHIBITING eIF4E}

\section{Targeting the eIF4E-Cap Interaction}

Cap analogs have been used for the last 35 years to inhibit eIF4E cap-binding activity (primarily in in vitro biochemical assays), but assessment of their potential as antineoplastic agents is hindered by poor cell permeability and in vivo stability (Wagner et al. 2000). Cocrystal structures of eIF4E with cap analogs have defined the key features critical for cap recognition (Marcotrigiano et al. 1997, 1999; Niedzwiecka et al. 2002; Tomoo et al. 2002). These include the delocalized positive charge of the 7-methyl guanosine ring, which forms cation- $\pi$ stacking interactions with Trp56 and Trp102, a hydrogen-bonding interaction between the guanine carbonyl group and the backbone amide of Trp102, hydrogen bond engagement of guanine N1 and N2 with Glu103, and a hydrogen bonding network between phosphates, and mediated through water, with Arg112, Arg157, and Lys162 (Fig. 3A). This latter feature explains the higher binding affinity of $\mathrm{m}^{7} \mathrm{GTP}$ for eIF4E relative to $\mathrm{m}^{7} \mathrm{GDP}$ (39-fold) and $\mathrm{m}^{7} \mathrm{GMP}$ (407-fold). The eIF4E cap-binding pocket has three cavities that can accommodate extensions from the N7 position, and this explains why compounds that harbor bulky N7 substituents, like N7-benzyl GMP and 7-( $p$-fluorobenzyl)GMP, still function as cap analogs (Brown et al. 2007). This insight was used to design a novel guanine analog (Cmpd \#33) that showed a 147-fold increase in binding affinity for eIF4E compared with $\mathrm{m}^{7} \mathrm{GMP}$ (Fig. 3B) (Chen et al. 2012b). Unfortunately, Cmpd \#33 suffers from poor cellular permeability.

To overcome this liability, Wagner and colleagues (Wagner et al. 2000) developed 4Ei-1, an N7-benzyl GMP tryptamine phosphoramidate pronucelotide (Fig. 3B) that is cell permeable and converts to the biologically active compound, 7-benzyl guanosine monophosphate in cells (Ghosh et al. 2009). 4Ei-1 has been shown to block the epithelial-to-mesenchymal transition in zebrafish (Ghosh et al. 2009) and in lung epithelial cells by inhibiting translation of Snail1 (Smith et al. 2015). It also chemosensitizes lung cancer cells to gemcitabine (Li et al. 2013) and mesothelioma cells to pemetrexed (Chen et al. 2014).

\section{Targeting the elF4E:elF4G Interaction}

Two independently conducted high throughput screens led to the discovery of three eIF4E:eIF4G interaction inhibitors: 4EGI-1, 4E1RCat, and 4E2RCat (Fig. 3C) (Moerke et al. 2007; Cencic et al. 2011a). Compound 4EGI-1 (which exists as two interconverting isomeric forms, $\mathrm{E}$ and $\mathrm{Z}$ ) binds to eIF4E at a location removed from the eIF4G-binding site and causes local conforma- 


\section{J. Chu and J. Pelletier}
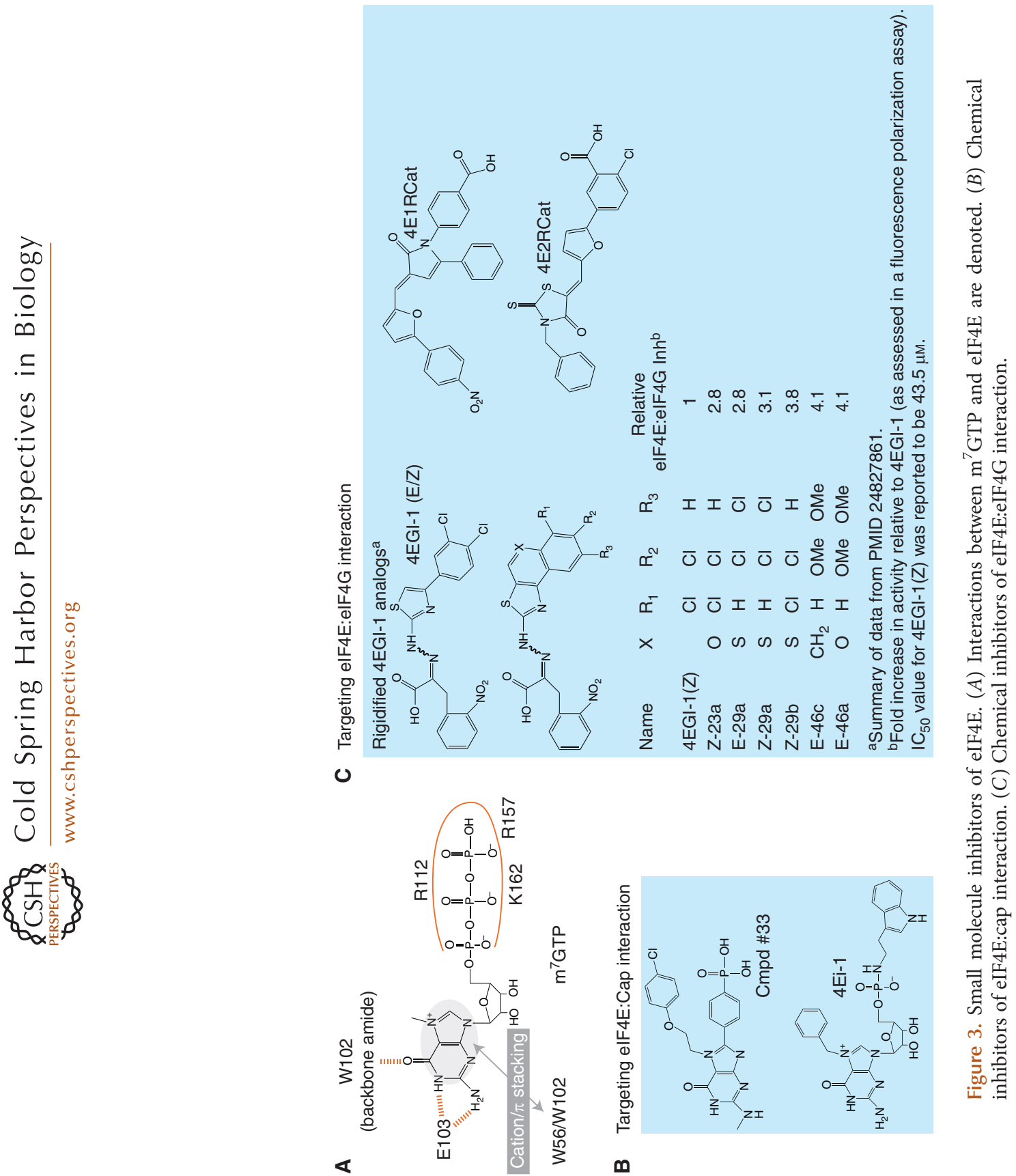
tional changes that lead to disengagement of eIF4G from eIF4E (Papadopoulos et al. 2014). An unexpected property of $4 \mathrm{EGI}-1$ is that it increases 4E-BP1 binding to eIF4E in cells (Moerke et al. 2007). 4EGI-1 inhibits expression of known eIF4F-responsive mRNAs, such as cyclins D1 and E, c-MYC, and BCL-2 (Moerke et al. 2007), and blocks the hypoxia-induced gene-activation program (Yi et al. 2013). It selectively kills transformed cells more than nontransformed cells (Moerke et al. 2007; Tamburini et al. 2009) and shows efficacy in several cancer models, including U87 glioma, breast, and melanoma xenograft models (Chen et al. 2012a; Descamps et al. 2012; Wu et al. 2016) and against multiple myeloma (Descamps et al. 2012) and melanoma cell lines (Mahalingam et al. 2014). 4EGI-1 also impairs mitochondrial function (Yang et al. 2015). This compound has been used in studies to probe the role of eIF4F in memory, autism, and viral replication (Hoeffer et al. 2011; McMahon et al. 2011; Gkogkas et al. 2013; Santini et al. 2013). Rigidified variants of 4EGI-1 have been synthesized and characterized, with some capable of better inhibiting the eIF4E:eIF4G interaction than the parental compound (Fig. 3C) (Mahalingam et al. 2014).

4E1RCat and 4E2RCat prevent the association of both eIF4G and 4EBP1 with eIF4E (Fig. 3C) (Cencic et al. 2011a). 4E1RCat dampened protein synthesis by $\sim 30 \%$ in Jurkat cells (Cencic et al. 2011a). 4E1RCat is pharmacologically active in mice and was shown to synergize with doxorubicin in a mouse lymphoma model, prolonging tumor-free survival compared with single-agent-treated cohorts (Cencic et al. 2011a). 4E1RCat blocks mitosis-restricted protein synthesis (Shuda et al. 2015) and decreases MCL-1 levels in HL-1 cardiomyocytes (Arnold et al. 2014). 4E1RCat and 4E2RCat have been used to block coronavirus replication (Cencic et al. 2011b).

\section{Targeting elF4A}

There are two related eIF4A homologs in mammals, eIF4A1 and eIF4A2, which share 90\% identity at the amino acid level (Nielsen and
Trachsel 1988; Galicia-Vazquez et al. 2012). Accurate quantitation of the two proteins has not been extensively performed across a large number of cell or tissue types. At the mRNA level, eIF4A1 is generally more abundantly expressed with notable exceptions being in fetal brain, heart, and kidney and adult brain, ovary, and skeletal muscle (Galicia-Vazquez et al. 2012). eIF4A is an abundant factor (about three to six molecules/ribosome) with the majority ( $\sim 90 \%)$ existing outside of the eIF4F complex. Both eIF4A1 and eIF4A2 can assemble into the eIF4F complex. eIF4A1 suppression is not well tolerated, whereas eIF4A2 can be completely eliminated in NIH 3T3 fibroblast cells using CRISPR/Cas9 with no detectable effects on protein synthesis rates, proliferation, and viability. An analysis of the viability of 398 cancer cells lines in which eIF4A1 or eIF4A2 expression was suppressed using shRNAs (21 shRNAs targeting eIF4A1 and 19 shRNAs targeting eIF4A2 were used in this study) is consistent with eIF4A1, but not eIF4A2, being essential (McDonald et al. 2017). Three natural products, pateamine A (PatA), hippuristanol, and rocaglate family members have been identified as selective and potent eIF4A inhibitors.

\section{Pateamine $A$}

PatA is a naturally occurring metabolite isolated from the marine sponge Mycale hentscheli and was originally found to have potent cytotoxic activity against P388 leukemia cells (half-maximal inhibitory concentration, $\mathrm{IC}_{50}=0.27 \mathrm{nM}$ ) (Northcote et al. 1991). Initial efforts to identify the molecular target of PatA involved affinity chromatography of total cell extracts prepared from HL60 cells using immobilized PatA, in which cytokeratin, tubulin, eIF4A1, eIF4A2, and eIF4A3 (DDX48) were retained (Bordeleau et al. 2005). In a separate set of experiments, also using immobilized PatA, eIF4A1 and serine/ threonine kinase receptor associated protein (STRAP) were captured from RKO colorectal carcinoma cell extracts (Low et al. 2005). Overexpression of eIF4A1, but not STRAP, in HeLa cells increased the PatA $\mathrm{IC}_{50}$ fivefold suggesting that inhibition of eIF4A is primarily responsible 
for PatA's ability to block cell proliferation (Low et al. 2005). In addition to inhibiting translation through targeting eIF4A1 and/or eIF4A2, PatA also impedes nonsense-mediated mRNA decay by targeting eIF4A3, a core component of the exon junction complex (Dang et al. 2006). PatA is not a pan-helicase inhibitor as it does not block Ded1p helicase activity, in vitro splicing reactions, or cellular DNA and RNA synthesis (Bordeleau et al. 2005). Moreover, PatA does not inhibit prokaryotic translation (Bordeleau et al. 2005).

With respect to its mechanism of action, PatA increases the ATP hydrolysis rate and RNA-binding ability of free eIF4A (Bordeleau et al. 2005; Low et al. 2005), but not if eIF4A is present in the eIF4F complex (Bordeleau et al. 2005), suggesting that binding of eIF4A to eIF4G might occlude PatA binding. Exposure of cells to PatA reduces the levels of eIF4A1 found within the eIF4F complex (Low et al. 2005). On the other hand, high concentrations of PatA $(10 \mu \mathrm{M})$ have been reported to stimulate the interaction between eIF4A and eIF4B (Low et al. 2005), but this may be an indirect effect mediated by a bridging RNA fragment (Bordeleau et al. 2006b). Taken together, the current body of evidence depicts PatA as a compound that forces nonspecific eIF4A-RNA engagements, depleting eIF4A from the eIF4F complex with concomitant inhibition of cap-dependent translation (Bordeleau et al. 2006b). PatA blocks $48 \mathrm{~S}$ complex formation in vitro and PatA-exposed cells have reduced polysomes (Bordeleau et al. 2005). The hepatitis $C$ virus internal ribosome entry site (HCV IRES), which does not require any of the eIF4F subunits for initiation, is significantly more resistant to inhibition by PatA (Bordeleau et al. 2005; Low et al. 2005). As an inhibitor of translation, PatA also induces the assembly of stress granules (Dang et al. 2006; Mazroui et al. 2006). Although the PatA-binding site on eIF4A has yet to be determined, it may be located within the eIF4A amino-terminal domain (NTD) because a carboxy-terminal deletion of eIF4A $(\Delta 246-406)$ is still capable of binding PatA (Low et al. 2007).

The total chemical synthesis of PatA has been reported and second-generation analogs have been prepared (Romo et al. 2004; Kuznetsov et al. 2009; Low et al. 2014). One analog, DMDA-PatA, has comparable cytotoxicity and activity toward eIF4A as PatA. PatA is an irreversible inhibitor of translation, possibly caused by the presence of a Michael addition site on this compound (Bordeleau et al. 2005; Low et al. 2005) and analogs lacking this feature are no longer cytotoxic (Low et al. 2014). PatA and DMDA-PatA inhibit proliferation and induce apoptosis in many tumor cell lines at nanomolar concentrations ex vivo as well as in melanoma xenograft models (Northcote et al. 1991; Hood et al. 2001; Low et al. 2005; Kuznetsov et al. 2009). DMDA-PatA is not a substrate for multidrug resistance protein 1 (MDR1) (Kuznetsov et al. 2009), a protein in which overexpression is associated with intrinsic and acquired drug resistance (Hodges et al. 2011).

\section{Hippuristanol}

Hippuristanol is a polyoxygenated steroid first isolated from the gorgonian Isis hippuris (Higa and Tanaka 1981; Higa et al. 1981). It prevents eIF4A from interacting with RNA without affecting ATP binding (Bordeleau et al. 2006a). The binding site for hippuristanol resides in the eIF4A carboxy-terminal domain (CTD) and involves amino acids spanning, and adjacent to, motifs $\mathrm{V}$ and VI, which are two regions that are conserved among DEAD-box RNA helicases and that participate in RNA and ATP binding (Bordeleau et al. 2006a; Lindqvist et al. 2008). The amino acids flanking motifs $\mathrm{V}$ and VI are not conserved among other DEAD-box helicases, providing an explanation for the specificity of hippuristanol toward eIF4A.

Hippuristanol has been used to link eIF4Adependent initiation events to long-term synaptic potentiation (Ran et al. 2009; Hoeffer et al. 2013), herpes simplex virus 1 host shutoff (Dauber et al. 2011; Radtke et al. 2013), and influenza virus mRNA translation (Yángüez et al. 2011). Hippuristanol shows single-agent activity against DBA/MC fibrosarcoma cells (Higa et al. 1981), multiple myeloma cells (Robert et al. 2014), Burkitt lymphoma cells (Cencic et al. 2013), adult T-cell leukemia cells in vitro 
and in vivo (Tsumuraya et al. 2011), and against lymphocytic leukemia P-388 tumors in mice (Higa et al. 1981). Combining hippuristanol with vemurafenib (anti-B-Raf therapy) (Boussemart et al. 2014), ABT-737 (Cencic et al. 2013), doxorubicin (Cencic et al. 2013), or dexamethasone (Robert et al. 2014) overcomes resistance to the initial therapy, an effect that is also obtained with rocaglates (see below), implying a role for eIF4A-dependent translation in drug resistance.

Several synthetic routes to hippuristanol have been reported ( $\mathrm{Li}$ et al. 2009; Ravindar et al. 2010, 2011; Somaiah et al. 2014). These provided some insight into structure-activity relationships (SAR) with respect to translation inhibition (Li et al. 2009; Somaiah et al. 2014) and cellular cytotoxicity (Li et al. 2009). However, our understanding of hippuristanol SAR is still limited because of an inability to synthetically access functionality at a large number of locations on this molecule. To date, no analog has been made that has equivalent or greater potency toward inhibiting translation than hippuristanol.

\section{Rocaglates}

Rocaglates originated from plants of the Aglaia genus. They interact directly with eIF4A as determined by affinity chromatography (Chambers et al. 2013), differential scanning fluorimetry (Chu et al. 2016b), and cellular thermal shift assay (CETSA) (Chu et al. 2016b). A significant body of work has shown that rocaglates possess single-agent activity in a variety of cancer models, reverse the chemoresistance phenotype in a number of settings (including toward PI3K/ mTOR and RAS/MAPK pathway inhibitors), and also affect tumor-supportive processes such as angiogenesis (reviewed in Bhat et al. 2015; Chu and Pelletier 2015). Importantly, through the generation of an eIF4A rocaglateresistant allele using CRISPR/Cas9, the in vivo antiproliferative property of this class of compounds toward tumor cells has been shown to be a direct consequence of eIF4A1 inhibition (Chu et al. 2016b).

There has been significant interest in identifying mRNA features that modulate rocaglate sensitivity. Ribosome profiling analysis of MDAMB-231 breast cancer cells treated for $2 \mathrm{~h}$ with $25 \mathrm{~nm}$ silvestrol yielded modest repression of global translation, with only $3.3 \%$ of translating mRNAs being markedly inhibited (Rubio et al. 2014). These mRNAs had $5^{\prime}$ leaders with longer, structured sequences and relatively low overall guanine-cytosine (GC) content compared with nonresponsive mRNAs (Rubio et al. 2014). Ribosome profiling analysis of KOPT-K1 T acute lymphoblastic leukemia cells exposed to $25 \mathrm{~nm}$ silvestrol for $45 \mathrm{~min}$ also identified $5^{\prime}$ leader length as a silvestrol responsive feature (Wolfe et al. 2014). In addition, $\sim 1 / 3$ of silvestrol-responsive mRNAs harbored a putative Gquadruplex, a feature previously shown to confer rocaglate responsiveness (Cencic et al. 2009). A third study examined the consequences on translation in HEK 293 cells treated with the rocaglate, RocA (Iwasaki et al. 2016), and found that RocA-responsiveness did not correlate with the thermodynamic stability of the $5^{\prime}$ leader or the presence of G-quadruplexes (Iwasaki et al. 2016). Using a Bind-n-Seq approach, a highthroughput method by which to identify in vitro protein-RNA interactions, revealed that RocA leads to clamping of eIF4A onto RNA-containing polypurine sequences (4-6 nts in length). In vitro experiments revealed that this clamping, when it occurs on mRNAs, can lead to reduced initiation events at start codons residing downstream from the polypurine stretch, suggesting impaired ribosome scanning. Rocaglates can also block eIF4F activity because cells exposed to these have reduced levels of eIF4A in the eIF4F complex, an effect that will block $48 \mathrm{~S}$ preinitiation complex formation (Bordeleau et al. 2008; Cencic et al. 2009).

\section{Targeting elF4G}

eIF4G remains a largely unexplored drug target. Virtual docking experiments aimed at identifying novel inhibitors of AKT led to the discovery of BI-69A11, a compound that unexpectedly was also found to bind to eIF4G1 following mass spectrometry analysis of proteins from UACC903 cells retained using biotinylated BI69A11 (Gaitonde et al. 2009; Feng et al. 2015). 
The pursuit of analogs with better pharmacokinetic properties led to the development of SBI0640756 (SBI-756) (Feng et al. 2015). Isolation of eIF4F by cap-analog affinity chromatography from mouse embryonic fibroblast (MEF) cell extracts revealed partial loss of eIF4G in SBI756-treated cells. SBI-756 inhibits AKT and NF- $\kappa \mathrm{B}$ activity and blocks growth of NF1-mutant, NRas-mutant, and BRAF-resistant melanoma cells (Feng et al. 2015). Nontransformed fibroblasts are threefold less sensitive than A375 or UACC903 melanoma cells to the cytotoxic effects of SBI-756. It will be important to determine to what extent these biological effects are a consequence of eIF4G perturbation versus other activities that this compound may have.

\section{INHIBITING eIF2}

Perturbing elF2 Activity

Blocking Dephosphorylation of Phospho-elF2 $\alpha$

Ser/Thr protein phosphatase 1 can be recruited to dephosphorylate eIF2 $\alpha$ by either GADD34 or $\mathrm{CReP}$, the two proteins shown to blunt the endoplasmic reticulum (ER) stress response (Novoa et al. 2001; Jousse et al. 2003). Because GADD34 enhances the toxicity of ER stress and GADD $34^{-/-}$mice develop normally (Marciniak et al. 2004), it was postulated that GADD34 inhibition might be of therapeutic benefit. To this end, a screen was undertaken in search of compounds (19,000 molecules tested) that could protect rat PC12 cells against ER stressinduced apoptosis (Boyce et al. 2005). Salubrinal, and a more potent and soluble derivative (Sal003) (Robert et al. 2006), were found to prevent the dephosphorylation of phospho-eIF $2 \alpha$, likely by blocking the conserved PP1-binding domain of GADD34 and CReP (Boyce et al. 2005; Fullwood et al. 2012). These compounds have been used to show protective effects in a number of neurodegenerative disease models driven by ER stress that include (1) amyloid $\beta$ protein aggregation (Hoozemans et al. 2009; Lee et al. 2010); (2) mutant Huntingtin aggregation (Reijonen et al. 2008); (3) misexpression of $\alpha$ - synuclein seen in Parkinson's disease (Smith et al. 2005); and (4) polyubiquitinated protein build up in a transgenic model of amyotrophic lateral sclerosis (Saxena et al. 2009). These results are difficult to reconcile with those of genetic experiments in which loss of PERK in mice expressing a familial AD-related mutation in APP and PSEN1 prevented deficits in synaptic plasticity and spatial memory associated with this model (Ma et al. 2013). It is possible that the differences are caused by salubrinal having additional activity (which has not been systematically assessed), to the timing of changes in eIF2 $\alpha$ phosphorylation status (e.g., loss of PERK before onset of $\mathrm{AD}$ pathology versus maintenance of phospho-eIF $2 \alpha$ levels during ER stress), or to differences in the models used. Salubrinal has been shown capable of resensitizing multiple myeloma cells to bortezomib (Schewe and Aguirre-Ghiso 2009). Current compound liabilities include low solubility and poor bioavailability (Long et al. 2005).

Guanabenz is a drug used to treat hypertension and acts as an $\alpha 2$-adrenergic agonist. It binds to GADD34, but not CReP, and disrupts its interaction with PP1 $\alpha$. Guanabenz is capable of rescuing cells from protein misfolding stress (Tsaytler et al. 2011) and blocks the proliferation, survival, and invasion of $4 \mathrm{~T} 1$ and MDA-MB-231 mammary tumor cells (Hamamura et al. 2014). These results are exciting given the clinical experience with Guanabez and its known safety profile and are encouraging for future strategies aimed at pharmacologically modulating ER stress.

\section{Blocking elF2 $\alpha$ Function}

Another manner by which eIF2 function can be blocked is highlighted by experiments with NSC119889 and NSC119893, two fluorescein derivatives that prevent the binding of Met$\mathrm{tRNA}_{\mathrm{i}}^{\mathrm{Met}}$ to eIF2 (Robert et al. 2006). These compounds were used to show a reduced requirement of the HCV IRES for TCs (Robert et al. 2006); the HCV IRES can use eIF5B, eIF3, and eIF2A for translation initiation under stress (Terenin et al. 2008; Kim et al. 2011). 


\section{Targeting elF $2 B$}

Using a luciferase reporter-based screen, Sidrauski et al. (2012) identified ISRIB (integrated stress response inhibitor), a compound that inhibits PERK-mediated activation of ATF4 translation. The trans-isomer ISRIB-A1 is $100-$ fold more potent than its cis-isomer (Sidrauski et al. 2015a). ISRIB-A1 does not diminish PERK phosphorylation (if anything, an increase is observed) nor does it affect eIF2 $\alpha$ phosphorylation in ER-stressed cells (Sidrauski et al. 2015a). Yet, global translation rates are sustained in ISRIBtreated cells in the face of ER stress or when the eIF2 $\alpha$ S51D phosphomimetic allele is introduced into cells. In fact, ISRIB blocks the integrated stress response (ISR) triggered by all eIF2 $\alpha$ kinases (Sidrauski et al. 2012). Memory consolidation and enhancement are limited by the ISR and ISRIB-treated mice display enhanced spatial and fear-associated learning ( $\mathrm{Si}$ drauski et al. 2012). ISRIB completely reverses the translational effects elicited by eIF $2 \alpha$ phosphorylation and induces no major change in mRNA translation or levels in treated cells (Sidrauski et al. 2015b). At the molecular level, ISRIB likely overcomes the effects of eIF $2 \alpha$ phosphorylation by acting on eIF2B. ISRIB causes dimerization of eIF2B, enhances the thermostability of the eIF2B $\delta$ subunit in the CETSA assay, and enhances the GEF activity of eIF2B (Sidrauski et al. 2015a). Amino acid changes within the amino terminus of the eIF2B $\delta$ subunit confer ISRIB resistance (Sekine et al. 2015). Analogs with higher potencies are currently sought after and, one such compound, ISRIBA17, has been found to be 10 -fold more potent than the parental ISRIB-A1 compound (Sidrauski et al. 2015a; Hearn et al. 2016).

\section{Modulating elF2 $\alpha$ Kinase Activity}

Many compounds have been identified that cause an increase in phospho-eIF $2 \alpha$ levels, but data are lacking regarding the specificity of these compounds and there is a paucity of genetic information linking their biological activity to changes in phospho-eIF $2 \alpha$ levels. For example, the flavonoids, genisten, and quercetin, are cy- totoxic to tumor cells in vitro and induce eIF $2 \alpha$ phosphorylation at high concentrations $(100 \mu \mathrm{M})$ (Ito et al. 1999). However, supporting genetic data are needed to link changes in phosphoeIF $2 \alpha$ levels to the biological activity of these (and other) compounds, especially because genisten (Yan et al. 2010) and quercetin (Boly et al. 2011) are known tyrosine and serine/threonine kinase inhibitors and exert profound effects on the phosphoproteome.

1. Heme-regulated inhibitor (HRI). There are two known modulators of HRI activity: aminopyrazolindane and $N, N^{\prime}$-diarylureas. Aminopyrazolindane was identified as an inhibitor from a screen reporting on HRI kinase activity (Garcia-Villegas et al. 2009). This compound suffers from low bioavailability and very rapid clearance in rats (Garcia-Villegas et al. 2009). A screen of 102,000 small molecules identified $N, N^{\prime}$-diarylureas as a class of compounds capable of activating HRI and inducing eIF2 $\alpha$ phosphorylation (Chen et al. 2011; Denoyelle et al. 2012). $N, N^{\prime}$-diarylureas interact directly with HRI, as determined by nuclear magnetic resonance (NMR) and by drug affinity-responsive target stability (DARTS ), an assay that assesses small molecule binding to target by monitoring protection against proteolytic degradation (Chen et al. 2011). N, $N^{\prime}$-diarylureas reduce proliferation of tumor cells, which is an effect linked to enhanced eIF $2 \alpha$ phosphorylation because ectopic expression of eIF $2 \alpha^{\mathrm{S} 51 \mathrm{~A}}$ rescued the proliferative block. A subsequent screen of a 1900 member $N, N^{\prime}$ disubstituted urea library identified a compound ( $N$-aryl, $N^{\prime}$-cyclohexylphenoxyurea) that significantly increased eIF2 $\alpha$ phosphorylation and CHOP synthesis (Chen et al. 2013). We note that because the diarylurea scaffold is a widely used framework for the design of receptor tyrosine kinase (RTK) inhibitors (Shan et al. 2016), it will be important to link the biological activity of new compounds to changes in eIF $2 \alpha$ phosphorylation.

2. PKR. There have been a number of PKR inhibitors described in the literature. The compound 2-amino purine was the first reported 
inhibitor of PKR, but is neither very potent nor selective (Huang and Schneider 1990). Another inhibitor (Cmpd \#16) was isolated by the Beal Laboratory (Jammi et al. 2003) from a collection of ATP site inhibitors and shown to be capable of rescuing a translational block imposed in vitro using a recombinant glutathione $S$-transferase (GST) fusion containing the PKR kinase domain. This compound is able to rescue translation inhibition caused by PKR in cells (Eley et al. 2007). In a separate study, a collection of kinase inhibitors was screened for their ability to block PKR activity (Bryk et al. 2011). Pharmacophore modeling of these hits (and of those from the Beal Laboratory screen [Jammi et al. 2003]), followed by an in silico screen of 15 million compounds identified several novel compounds that showed activity toward PKR, although their selectivity for PKR over other kinases remains to be established.

3. GCN2. An autophosphorylation assay was used to identify GCN2 kinase domain inhibitors. From a collection of kinase inhibitors, three compounds (indirubine- $3^{\prime}$-monoxime, SP600124, and staurosporine) were identified (Robert et al. 2009b). Evaluation of 14 different indirubine- $3^{\prime}$-monoxime analogs identified Syk1 (spleen tyrosine kinase inhibitor) as having equipotent activity as the parental compound. Inhibition of GCN2 in cells with these compounds showed a protective effect against UV-induced eIF $2 \alpha$ phosphorylation (Deng et al. 2002).

4. PERK. A phenotype-based screen was implemented based on ectopic expression of a CHOP-luciferase fusion mRNA in $\mathrm{CHO}$ cells designed to report on ISR induction (Harding et al. 2005). Two hits were identified from this screen, TGD31 and TGD45, both of which were subsequently benzoylated to improve cell permeability, leading to the generation of TGD31 and TG45BZ. Treatment of cells with TG45BZ causes ER stress and activation of PERK, but not of GCN2 or PKR (HRI activation could not be assessed because of its low expression level in fibro- blasts). The ISR induced by these compounds is thought to be promoted by activation of PERK as well as additional contributing mechanisms, because ISR markers were also induced in TGD45BZ-treated PERK ${ }^{-/-}$ MEFs (Harding et al. 2005).

Structure-guided in silico docking was used to identify a different set of compounds with activity toward PERK, but kinome-wide assessment of their activities is lacking (Wang et al. 2010). In an assay assessing eIF $2 \alpha$ phosphorylation by GST-PERK, a theinopyrimidinecontaining compound was identified from a collection of kinase inhibitors and inhibited PERK with an $\mathrm{IC}_{50}$ of $11 \mathrm{~nm}$ (Axten et al. 2012). A series of analogs was generated, and informed by PERK-inhibitor cocrystal structures, GSK2606414 was developed. Kinome profiling showed extremely high selectivity for PERK and xenograft studies showed that this compound could reduce pancreatic tumor growth with no notable side effects (Axten et al. 2012). Medicinal chemistry optimization led to the development of GSK2656157, displaying an $\mathrm{IC}_{50}$ of $0.9 \mathrm{~nm}$ against PERK and impressive selectivity; among 300 kinases tested against GSK2656157, the most potent off-target activity was against HRI ( $\mathrm{IC}_{50}$ of $460 \mathrm{nM}$ ) (Atkins et al. 2013; Axten et al. 2013). This compound reduced tumor outgrowth in xenograft settings established from pancreatic and multiple myeloma cells, as well as reduced angiogenesis and vascular perfusion. GSK2606414 and GSK2656157 have recently been shown to inhibit RIPK1 and induce RIPK1-kinase dependent cell death in a PERK-independent manner, indicating an off-target biological activity (Rojas-Rivera et al. 2017).

\section{FUTURE PERSPECTIVE}

A number of exciting opportunities remain for the discovery of small molecules targeting translation initiation. The interaction between eIF4A and eIF4G and the association between eIF4G and MNK1/2 have not been exploited for compound discovery. In addition, compounds that discriminate between eIF4A1, eIF4A2, eIF4G1, 
Translating Therapeutics

and eIF4G3 activity would be useful to tease out potential differences among these factors in the translation process.

Recently, eIF2A, a factor that binds MettRNAi (but not GTP) and interacts with $40 \mathrm{~S}$ ribosomes in a codon-dependent manner, has been identified as an essential factor required for tumor initiation in squamous cell carcinoma (Sendoel et al. 2017). It is thought that eIF2A mediates initiation at upstream ORFs (uORFs), imparting a profound effect on the cellular proteome. eIF2A $\mathrm{A}^{-/-}$mice are viable (Golovko et al. 2016), indicating that eIF2A inhibitors might affect normal cells minimally and produce few or minor side effects, while significantly impacting on tumor cell survival.

New compounds targeting other translation factors would be enormously helpful as tools to define whether these play critical roles in normal and abnormal physiology. For example, the multifactorial complex eIF3 has been implicated as a translational activator or repressor by binding to specific RNA elements, has cap-binding activity, promotes reinitiation, and overexpression of some of its subunits is oncogenic (Zhang et al. 2007; Roy et al. 2010; Hershey 2015; Lee et al. 2015, 2016; Kumar et al. 2016). A better understanding of the role of eIF3 in the initiation process may provide insight into the molecular basis of different translation initiation pathways. Likewise, the role that eIF4B plays in preinitiation complex recruitment, in stimulating eIF4A helicase activity, and unraveling its putative eIF4A-independent function in translation still remain to be elucidated. Hence, future progress in this field holds promise to shed light on the fundamental process of translation and offers the exciting possibility of uncovering novel therapeutic strategies and compounds.

\section{ACKNOWLEDGMENTS}

Research on this topic in J.P.'s laboratory has been made possible through support from the Canadian Institutes of Health Research and the Richard and Edith Strauss Canada Foundation.

\section{REFERENCES}

${ }^{*}$ Reference is also in this collection.

Alain T, Morita M, Fonseca BD, Yanagiya A, Siddiqui N, Bhat M, Zammit D, Marcus V, Metrakos P, Voyer LA, et al. 2012. eIF4E/4E-BP ratio predicts the efficacy of mTOR targeted therapies. Cancer Res 72: 6468-6476.

Alvandi F, Kwitkowski VE, Ko CW, Rothmann MD, Ricci S, Saber H, Ghosh D, Brown J, Pfeiler E, Chikhale E, et al. 2014. U.S. Food and Drug Administration approval summary: Omacetaxine mepesuccinate as treatment for chronic myeloid leukemia. Oncologist 19: 94-99.

Arnold N, Koppula PR, Gul R, Luck C, Pulakat L. 2014. Regulation of cardiac expression of the diabetic marker microRNA miR-29. PLOS ONE 9: e103284.

Atkins C, Liu Q, Minthorn E, Zhang SY, Figueroa DJ, Moss K, Stanley TB, Sanders B, Goetz A, Gaul N, et al. 2013 Characterization of a novel PERK kinase inhibitor with antitumor and antiangiogenic activity. Cancer Res 73: 1993-2002.

Axten JM, Medina JR, Feng Y, Shu A, Romeril SP, Grant SW, Li WH, Heerding DA, Minthorn E, Mencken T, et al. 2012. Discovery of 7-methyl-5-(1-\{[3-(trifluoromethyl) phenyl] acetyl $\}-2,3$-dihydro- $1 H$-indol-5-yl)-7H-pyrrolo [2,3-d]pyrimidin-4-amine (GSK2606414), a potent and selective first-in-class inhibitor of protein kinase $R$ (PKR)-like endoplasmic reticulum kinase (PERK). J Med Chem 55: 7193-7207.

Axten JM, Romeril SP, Shu A, Ralph J, Medina JR, Feng Y, Li WH, Grant SW, Heerding DA, Minthorn E, et al. 2013. Discovery of GSK2656157: An optimized PERK inhibitor selected for preclinical development. ACS Med Chem Lett 4: 964-968.

Baragaña B, Hallyburton I, Lee MC, Norcross NR, Grimaldi R, Otto TD, Proto WR, Blagborough AM, Meister S, Wirjanata $G$, et al. 2015. A novel multiple-stage antimalarial agent that inhibits protein synthesis. Nature 522: 315320.

Beroukhim R, Mermel CH, Porter D, Wei G, Raychaudhuri S, Donovan J, Barretina J, Boehm JS, Dobson J, Urashima $\mathrm{M}$, et al. 2010. The landscape of somatic copy-number alteration across human cancers. Nature 463: 899-905.

Bhat M, Robichaud N, Hulea L, Sonenberg N, Pelletier J, Topisirovic I. 2015. Targeting the translation machinery in cancer. Nat Rev Drug Discov 14: 261-278.

Bi M, Naczki C, Koritzinsky M, Fels D, Blais J, Hu N, Harding H, Novoa I, Varia M, Raleigh J, et al. 2005. ER stressregulated translation increases tolerance to extreme hypoxia and promotes tumor growth. EMBO $J \mathbf{2 4}$ 3470-3481.

Boly R, Gras T, Lamkami T, Guissou P, Serteyn D, Kiss R, Dubois J. 2011. Quercetin inhibits a large panel of kinases implicated in cancer cell biology. Int J Oncol 38: 833-842.

Bordeleau ME, Matthews J, Wojnar JM, Lindqvist L, Novac O, Jankowsky E, Sonenberg N, Northcote P, TeesdaleSpittle P, Pelletier J. 2005. Stimulation of mammalian translation initiation factor eIF4A activity by a small molecule inhibitor of eukaryotic translation. Proc Natl Acad Sci 102: 10460-10465.

Bordeleau ME, Mori A, Oberer M, Lindqvist L, Chard LS, Higa T, Belsham GJ, Wagner G, Tanaka J, Pelletier J. 
J. Chu and J. Pelletier

2006a. Functional characterization of IRESes by an inhibitor of the RNA helicase eIF4A. Nat Chem Biol 2: 213220.

Bordeleau ME, Cencic R, Lindqvist L, Oberer M, Northcote P, Wagner G, Pelletier J. 2006b. RNA-mediated sequestration of the RNA helicase eIF4A by pateamine A inhibits translation initiation. Chem Biol 13: 1287-1295.

Bordeleau ME, Robert F, Gerard B, Lindqvist L, Chen SM, Wendel HG, Brem B, Greger H, Lowe SW, Porco JA Jr, et al. 2008. Therapeutic suppression of translation initiation modulates chemosensitivity in a mouse lymphoma model. J Clin Invest 118: 2651-2660.

Boussemart L, Malka-Mahieu H, Girault I, Allard D, Hemmingsson $\mathrm{O}$, Tomasic G, Thomas M, Basmadjian C, Ribeiro N, Thuaud F, et al. 2014. eIF4F is a nexus of resistance to anti-BRAF and anti-MEK cancer therapies. Nature 513: 105-109.

Boyce M, Bryant KF, Jousse C, Long K, Harding HP, Scheuner D, Kaufman RJ, Ma D, Coen DM, Ron D, et al. 2005. A selective inhibitor of eIF $2 \alpha$ dephosphorylation protects cells from ER stress. Science 307: 935-939.

Brown CJ, McNae I, Fischer PM, Walkinshaw MD. 2007. Crystallographic and mass spectrometric characterisation of eIF4E with N7-alkylated cap derivatives. J Mol Biol 372: $7-15$.

Bryk R, Wu K, Raimundo BC, Boardman PE, Chao P, Conn GL, Anderson E, Cole JL, Duffy NP, Nathan C, et al. 2011. Identification of new inhibitors of protein kinase R guided by statistical modeling. Bioorg Med Chem Lett 21: 41084114.

Cargnello M, Roux PP. 2011. Activation and function of the MAPKs and their substrates, the MAPK-activated protein kinases. Microbiol Mol Biol Rev 75: 50-83.

Cencic R, Carrier M, Galicia-Vázquez G, Bordeleau ME, Sukarieh R, Bourdeau A, Brem B, Teodoro JG, Greger H, Tremblay ML, et al. 2009. Antitumor activity and mechanism of action of the cyclopenta $[b]$ benzofuran, silvestrol. PLOS ONE 4: e5223.

Cencic R, Hall DR, Robert F, Du Y, Min J, Li L, Qui M, Lewis I, Kurtkaya S, Dingledine R, et al. 2011a. Reversing chemoresistance by small molecule inhibition of the translation initiation complex eIF4F. Proc Natl Acad Sci 108: 1046-1051.

Cencic R, Desforges M, Hall DR, Kozakov D, Du Y, Min J, Dingledine R, Fu H, Vajda S, Talbot PJ, et al. 2011b. Blocking eIF4E-eIF4G interaction as a strategy to impair coronavirus replication. J Virol 85: 6381-6389.

Cencic R, Robert F, Galicia-Vázquez G, Malina A, Ravindar K, Somaiah R, Pierre P, Tanaka J, Deslongchamps P, Pelletier J. 2013. Modifying chemotherapy response by targeted inhibition of eukaryotic initiation factor $4 \mathrm{~A}$. Blood Cancer J 3: e128.

Chambers JM, Lindqvist LM, Webb A, Huang DC, Savage GP, Rizzacasa MA. 2013. Synthesis of biotinylated episilvestrol: Highly selective targeting of the translation factors eIF4AI/II. Org Lett 15: 1406-1409.

Chen R, Gandhi V, Plunkett W. 2006. A sequential blockade strategy for the design of combination therapies to overcome oncogene addiction in chronic myelogenous leukemia. Cancer Res 66: 10959-10966.

Chen T, Ozel D, Qiao Y, Harbinski F, Chen L, Denoyelle S, He X, Zvereva N, Supko JG, Chorev M, et al. 2011. Chem- ical genetics identify eIF2 $\alpha$ kinase heme-regulated inhibitor as an anticancer target. Nat Chem Biol 7: 610-616.

Chen L, Aktas BH, Wang Y, He X, Sahoo R, Zhang N, Denoyelle S, Kabha E, Yang H, Freedman RY, et al. 2012a. Tumor suppression by small molecule inhibitors of translation initiation. Oncotarget 3: 869-881.

Chen X, Kopecky DJ, Mihalic J, Jeffries S, Min X, Heath J, Deignan J, Lai S, Fu Z, Guimaraes C, et al. 2012b. Structure-guided design, synthesis, and evaluation of guaninederived inhibitors of the eIF4E mRNA-cap interaction. J Med Chem 55: 3837-3851.

Chen T, Takrouri K, Hee-Hwang S, Rana S, Yefidoff-Freedman R, Halperin J, Natarajan A, Morisseau C, Hammock B, Chorev M, et al. 2013. Explorations of substituted urea functionality for the discovery of new activators of the heme-regulated inhibitor kinase. J Med Chem 56: 94579470.

Chen EZ, Jacobson BA, Patel MR, Okon AM, Li S, Xiong K, Vaidya AJ, Bitterman PB, Wagner CR, Kratzke RA. 2014. Small-molecule inhibition of oncogenic eukaryotic protein translation in mesothelioma cells. Invest New Drugs 32: 598-603.

Choi Y, Kim HS, Shin KY, Kim EM, Kim M, Kim HS, Park CH, Jeong YH, Yoo J, Lee JP, et al. 2007. Minocycline attenuates neuronal cell death and improves cognitive impairment in Alzheimer's disease models. Neuropsychopharmacology 32: 2393-2404.

Chu J, Pelletier J. 2015. Targeting the eIF4A RNA helicase as an anti-neoplastic approach. Biochim Biophys Acta 1849: 781-791.

Chu J, Cargnello M, Topisirovic I, Pelletier J. 2016a. Translation initiation factors: Reprogramming protein synthesis in cancer. Trends Cell Biol 26: 918-933.

Chu J, Galicia-Vázquez G, Cencic R, Mills JR, Katigbak A, Porco JA Jr, Pelletier J. 2016b. CRISPR-mediated drugtarget validation reveals selective pharmacological inhibition of the RNA helicase, eIF4A. Cell Rep 15: 2340-2347.

Colina R, Costa-Mattioli M, Dowling RJ, Jaramillo M, Tai LH, Breitbach CJ, Martineau Y, Larsson O, Rong L, Svitkin YV, et al. 2008. Translational control of the innate immune response through IRF-7. Nature 452: 323-328.

Cope CL, Gilley R, Balmanno K, Sale MJ, Howarth KD, Hampson M, Smith PD, Guichard SM, Cook SJ. 2014. Adaptation to mTOR kinase inhibitors by amplification of eIF4E to maintain cap-dependent translation. J Cell Sci 127: 788-800.

Costa-Mattioli M, Gobert D, Stern E, Gamache K, Colina R, Cuello C, Sossin W, Kaufman R, Pelletier J, Rosenblum K, et al. 2007. eIF $2 \alpha$ phosphorylation bidirectionally regulates the switch from short- to long-term synaptic plasticity and memory. Cell 129: 195-206.

Dang Y, Kedersha N, Low WK, Romo D, Gorospe M, Kaufman R, Anderson P, Liu JO. 2006. Eukaryotic initiation factor $2 \alpha$-independent pathway of stress granule induction by the natural product pateamine A. J Biol Chem 281: 32870-32878.

Dauber B, Pelletier J, Smiley JR. 2011. The herpes simplex virus 1 vhs protein enhances translation of viral true late mRNAs and virus production in a cell type-dependent manner. J Virol 85: 5363-5373.

Deng J, Harding HP, Raught B, Gingras AC, Berlanga JJ, Scheuner D, Kaurman RJ, Ron D, Sonenberg N. 2002. 
Translating Therapeutics

Activation of GCN2 in UV-irradiated cells inhibits translation. Curr Biol 12: 1279-1286.

Denoyelle S, Chen T, Chen L, Wang Y, Klosi E, Halperin JA, Aktas BH, Chorev M. 2012. In vitro inhibition of translation initiation by $N, N^{\prime}$-diarylureas-Potential anti-cancer agents. Bioorg Med Chem Lett 22: 402-409.

Descamps G, Gomez-Bougie P, Tamburini J, Green A, Bouscary D, Maïga S, Moreau P, Le Gouill S, Pellat-Deceunynck C, Amiot M. 2012. The cap-translation inhibitor 4EGI-1 induces apoptosis in multiple myeloma through Noxa induction. Br J Cancer 106: 1660-1667.

Donze O, Jagus R, Koromilas AE, Hershey JW, Sonenberg N. 1995. Abrogation of translation initiation factor eIF-2 phosphorylation causes malignant transformation of NIH 3T3 cells. EMBO J 14: 3828-3834.

Dowling RJ, Topisirovic I, Alain T, Bidinosti M, Fonseca BD, Petroulakis E, Wang X, Larsson O, Selvaraj A, Liu Y, et al. 2010. mTORC1-mediated cell proliferation, but not cell growth, controlled by the 4E-BPs. Science 328: 1172 1176.

Duffy AG, Makarova-Rusher OV, Ulahannan SV, Rahma OE, Fioravanti S, Walker M, Abdullah S, Raffeld $M$, Anderson V, Abi-Jaoudeh N, et al. 2016. Modulation of tumor eIF4E by antisense inhibition: A phase I/II translational clinical trial of ISIS 183750-an antisense oligonucleotide against eIF4E-in combination with irinotecan in solid tumors and irinotecan-refractory colorectal cancer. Int J Cancer 139: 1648-1657.

Eberle J, Fecker LF, Bittner JU, Orfanos CE, Geilen CC. 2002. Decreased proliferation of human melanoma cell lines caused by antisense RNA against translation factor eIF4A1. Br J Cancer 86: 1957-1962.

Eley HL, Russell ST, Tisdale MJ. 2007. Attenuation of muscle atrophy in a murine model of cachexia by inhibition of the dsRNA-dependent protein kinase. Br J Cancer 96: 1216-1222.

Feng Y, Pinkerton AB, Hulea L, Zhang T, Davies MA, Grotegut S, Cheli Y, Yin H, Lau E, Kim H, et al. 2015. SBI0640756 attenuates the growth of clinically unresponsive melanomas by disrupting the eIF4F translation initiation complex. Cancer Res 75: 5211-5218.

Fullwood MJ, Zhou W, Shenolikar S. 2012. Targeting phosphorylation of eukaryotic initiation factor- $2 \alpha$ to treat human disease. Prog Mol Biol Transl Sci 106: 75-106.

Furic L, Rong L, Larsson O, Koumakpayi IH, Yoshida K, Brueschke A, Petroulakis E, Robichaud N, Pollak M, Gaboury LA, et al. 2010. eIF4E phosphorylation promotes tumorigenesis and is associated with prostate cancer progression. Proc Natl Acad Sci 107: 14134-14139.

Gaitonde S, De SK, Tcherpakov M, Dewing A, Yuan H, RielMehan M, Krajewski S, Robertson G, Pellecchia M, Ronai Z. 2009. BI-69A11-mediated inhibition of AKT leads to effective regression of xenograft melanoma. Pigment Cell Melanoma Res 22: 187-195.

Galicia-Vazquez G, Cencic R, Robert F, Agenor AQ, Pelletier J. 2012. A cellular response linking eIF4AI activity to eIF4AII transcription. RNA 18: 1373-1384.

Gantois I, Khoutorsky A, Popic J, Aguilar-Valles A, Freemantle E, Cao R, Sharma V, Pooters T, Nagpal A, Skalecka A, et al. 2017. Metformin ameliorates core deficits in a mouse model of fragile X syndrome. Nat Med 23: 674677.
Garcia-Villegas R, Lopez-Alvarez LE, Arni S, Rosenbaum T, Morales MA. 2009. Identification and functional characterization of the promoter of the mouse sodium-activated sodium channel $\mathrm{Na}_{\mathrm{x}}$ gene (Scn7a). J Neurosci Res 87: 2509-2519.

Garreau de Loubresse N, Prokhorova I, Holtkamp W, Rodnina MV, Yusupova G, Yusupov M. 2014. Structural basis for the inhibition of the eukaryotic ribosome. Nature 513: 517-522.

Getz MJ, Elder PK, Benz EW Jr, Stephens RE, Moses HL. 1976. Effect of cell proliferation on levels and diversity of poly(A)-containing mRNA. Cell 7: 255-265.

Ghosh B, Benyumov AO, Ghosh P, Jia Y, Avdulov S, Dahlberg PS, Peterson M, Smith K, Polunovsky VA, Bitterman PB, et al. 2009. Nontoxic chemical interdiction of the epithelial-to-mesenchymal transition by targeting capdependent translation. ACS Chem Biol 4: 367-377.

Gkogkas CG, Khoutorsky A, Ran I, Rampakakis E, Nevarko T, Weatherill DB, Vasuta C, Yee S, Truitt M, Dallaire P, et al. 2013. Autism-related deficits via dysregulated eIF4E-dependent translational control. Nature 493: 371-377.

Gkogkas CG, Khoutorsky A, Cao R, Jafarnejad SM, PragerKhoutorsky M, Giannakas N, Kaminari A, Fragkouli A, Nader K, Price TJ, et al. 2014. Pharmacogenetic inhibition of eIF4E-dependent Mmp9 mRNA translation reverses fragile X syndrome-like phenotypes. Cell Rep 9: 17421755.

Golovko A, Kojukhov A, Guan BJ, Morpurgo B, Merrick WC, Mazumder B, Hatzoglou M, Komar AA. 2016. The eIF2A knockout mouse. Cell Cycle 15: 3115-3120.

Graff JR, Boghaert ER, De Benedetti A, Tudor DL, Zimmer CC, Chan SK, Zimmer SG. 1995. Reduction of translation initiation factor $4 \mathrm{E}$ decreases the malignancy of ras-transformed cloned rat embryo fibroblasts. Int J Cancer 60: 255-263.

Graff JR, Konicek BW, Vincent TM, Lynch RL, Monteith D, Weir SN, Schwier P, Capen A, Goode RL, Dowless MS, et al. 2007. Therapeutic suppression of translation initiation factor eIF4E expression reduces tumor growth without toxicity. J Clin Invest 117: 2638-2648.

Halliday M, et al. 2017. Repurposed drugs targeting eIF2 $\alpha$ $\mathrm{P}$-mediated translational repression prevent neurodegeneration in mice. Brain 140: 1768-1783.

Hamamura K, Minami K, Tanjung N, Wan Q, Koizumi M, Matsuura N, Na S, Yokota H. 2014. Attenuation of malignant phenotypes of breast cancer cells through eIF2 $\alpha$-mediated downregulation of Rac1 signaling. Int $J$ Oncol 44: 1980-1988.

Harding HP, Zhang Y, Khersonsky S, Marciniak S, Scheuner D, Kaufman RJ, Javitt N, Chang YT, Ron D. 2005. Bioactive small molecules reveal antagonism between the integrated stress response and sterol-regulated gene expression. Cell Metab 2: 361-371.

Hearn BR, Jaishankar P, Sidrauski C, Tsai JC, Vedantham P, Fontaine SD, Walter P, Renslo AR. 2016. Structure-activity studies of bis-O-arylglycolamides: Inhibitors of the integrated stress response. ChemMedChem 11: 870-880.

Herbert TP, Fahraeus R, Prescott A, Lane DP, Proud CG. 2000. Rapid induction of apoptosis mediated by peptides that bind initiation factor eIF4E. Curr Biol 10: 793-796.

Hershey JW. 2015. The role of eIF3 and its individual subunits in cancer. Biochim Biophys Acta 1849: 792-800. 
J. Chu and J. Pelletier

Higa T, Tanaka J. 1981. 18-Oxygenated polyfunctional steroids from the gorgonian Isis hippuris. Tetrahed Lett $\mathbf{2 2}$ 2777-2780.

Higa T, Tanaka J, Tsukitani Y, Kikuchi H. 1981. Hippuristanols, cytotoxic polyoxygenated steroids from the gorgonian Isis hippuris. Chem Lett 10: 1647-1650.

Hodges LM, Markova SM, Chinn LW, Gow JM, Kroetz DL, Klein TE, Altman RB. 2011. Very important pharmacogene summary: ABCB1 (MDR1, P-glycoprotein). Pharmacogenet Genomics 21: 152-161.

Hoeffer CA, Cowansage KK, Arnold EC, Banko JL, Moerke NJ, Rodriguez R, Schmidt EK, Klosi E, Chorev M, Lloyd $\mathrm{RE}$, et al. 2011. Inhibition of the interactions between eukaryotic initiation factors $4 \mathrm{E}$ and $4 \mathrm{G}$ impairs longterm associative memory consolidation but not reconsolidation. Proc Natl Acad Sci 108: 3383-3388.

Hoeffer CA, Santini E, Ma T, Arnold EC, Whelan AM, Wong H, Pierre P, Pelletier J, Klann E. 2013. Multiple components of eIF4F are required for protein synthesis-dependent hippocampal long-term potentiation. J Neurophysiol 109: 68-76.

Holz MK, Ballif BA, Gygi SP, Blenis J. 2005. mTOR and S6K1 mediate assembly of the translation preinitiation complex through dynamic protein interchange and ordered phosphorylation events. Cell 123: 569-580.

Hong DS, Kurzrock R, Oh Y, Wheler J, Naing A, Brail L, Callies S, André V, Kadam SK, Nasir A, et al. 2011. A phase 1 dose escalation, pharmacokinetic, and pharmacodynamic evaluation of eIF-4E antisense oligonucleotide LY2275796 in patients with advanced cancer. Clin Cancer Res 17: 6582-6591.

Hood KA, West LM, Northcote PT, Berridge MV, Miller JH. 2001. Induction of apoptosis by the marine sponge ( $M y$ cale) metabolites, mycalamide A and pateamine. Apoptosis 6: 207-219.

Hoozemans JJ, van Haastert ES, Nijholt DA, Rozemuller AJ, Eikelenboom P, Scheper W. 2009. The unfolded protein response is activated in pretangle neurons in Alzheimer's disease hippocampus. Am J Pathol 174: 1241-1251.

Hou L, Antion MD, Hu D, Spencer CM, Paylor R, Klann E. 2006. Dynamic translational and proteasomal regulation of fragile X mental retardation protein controls mGluRdependent long-term depression. Neuron 51: 441-454.

Huang JT, Schneider RJ. 1990. Adenovirus inhibition of cellular protein synthesis is prevented by the drug 2-aminopurine. Proc Natl Acad Sci 87: 7115-7119.

Ilic N, Utermark T, Widlund HR, Roberts TM. 2011. PI3Ktargeted therapy can be evaded by gene amplification along the MYC-eukaryotic translation initiation factor 4E (eIF4E) axis. Proc Natl Acad Sci 108: E699-E708.

Ito T, Warnken SP, May WS. 1999. Protein synthesis inhibition by flavonoids: Roles of eukaryotic initiation factor 20 kinases. Biochem Biophys Res Commun 265: 589-594.

Iwasaki S, Floor SN, Ingolia NT. 2016. Rocaglates convert DEAD-box protein eIF4A into a sequence-selective translational repressor. Nature 534: 558-561.

Jammi NV, Whitby LR, Beal PA. 2003. Small molecule inhibitors of the RNA-dependent protein kinase. Biochem Biophys Res Commun 308: 50-57.

Jansen AP, Camalier CE, Colburn NH. 2005. Epidermal expression of the translation inhibitor programmed cell death 4 suppresses tumorigenesis. Cancer Res 65: 60346041 .

Jennings MD, Pavitt GD. 2014. A new function and complexity for protein translation initiation factor eIF2B. Cell Cycle 13: 2660-2665.

Jiang H, Coleman J, Miskimins R, Miskimins WK. 2003. Expression of constitutively active 4EBP-1 enhances p27 ${ }^{\text {Kip1 }}$ expression and inhibits proliferation of MCF7 breast cancer cells. Cancer Cell Int 3: 2.

Jiang HY, Wek RC. 2005a. Phosphorylation of eIF $2 \alpha$ reduces protein synthesis and enhances apoptosis in response to proteasome inhibition. J Biol Chem 280: 14189-14202.

Jiang HY, Wek RC. 2005b. GCN2 phosphorylation of eIF2 $\alpha$ activates NF- $\kappa \mathrm{B}$ in response to UV irradiation. Biochem $J$ 385: $371-380$.

Jousse C, Oyadomari S, Novoa I, Lu P, Zhang Y, Harding HP, Ron D. 2003. Inhibition of a constitutive translation initiation factor $2 \alpha$ phosphatase, $\mathrm{CReP}$, promotes survival of stressed cells. J Cell Biol 163: 767-775.

Kashiwagi K, Takahashi M, Nishimoto M, Hiyama TB, Higo T, Umehara T, Sakamoto K, Ito T, Yokoyama S. 2016. Crystal structure of eukaryotic translation initiation factor 2B. Nature 531: 122-125.

Kim JH, Park SM, Park JH, Keum SJ, Jang SK. 2011. eIF2A mediates translation of hepatitis $\mathrm{C}$ viral mRNA under stress conditions. EMBO J 30: 2454-2464.

Kim YK, Minai-Tehrani A, Lee JH, Cho CS, Cho MH, Jiang HL. 2013. Therapeutic efficiency of folated poly(ethylene glycol)-chitosan-graft-polyethylenimine- $P d c d 4$ complexes in H-ras $12 \mathrm{~V}$ mice with liver cancer. Int J Manomed 8: 1489-1498.

Ko SY, Guo H, Barengo N, Naora H. 2009. Inhibition of ovarian cancer growth by a tumor-targeting peptide that binds eukaryotic translation initiation factor $4 \mathrm{E}$. Clin Cancer Res 15: 4336-4347.

Koromilas AE, Mounir Z. 2013. Control of oncogenesis by eIF2 $\alpha$ phosphorylation: Implications in PTEN and PI3KAkt signaling and tumor treatment. Future Oncol 9: 1005-1015.

Kumar P, Hellen CU, Pestova TV. 2016. Toward the mechanism of eIF4F-mediated ribosomal attachment to mammalian capped mRNAs. Genes Dev 30: 1573-1588.

Kuznetsov G, Xu Q, Rudolph-Owen L, Tendyke K, Liu J, Towle M, Zhao N, Marsh J, Agoulnik S, Twine N, et al. 2009. Potent in vitro and in vivo anticancer activities of des-methyl, des-amino pateamine $\mathrm{A}$, a synthetic analogue of marine natural product pateamine A. Mol Cancer Ther 8: $1250-1260$.

Lazaris-Karatzas A, Montine KS, Sonenberg N. 1990. Malignant transformation by a eukaryotic initiation factor subunit that binds to mRNA $5^{\prime}$ cap. Nature 345: 544-547.

Lee DY, Lee KS, Lee HJ, Kim DH, Noh YH, Yu K, Jung HY, Lee SH, Lee JY, Youn YC, et al. 2010. Activation of PERK signaling attenuates $\mathrm{A} \beta$-mediated ER stress. PLoS ONE 5: e10489.

Lee AS, Kranzusch PJ, Cate JH. 2015. eIF3 targets cell-proliferation messenger RNAs for translational activation or repression. Nature 522: 111-114.

Lee AS, Kranzusch PJ, Doudna JA, Cate JH. 2016. eIF3d is an mRNA cap-binding protein that is required for specialized translation initiation. Nature 536: 96-99. 
Translating Therapeutics

Li W, Dang Y, Liu JO, Yu B. 2009. Expeditious synthesis of hippuristanol and congeners with potent antiproliferative activities. Chemistry 15: 10356-10359.

Li S, Jia Y, Jacobson B, McCauley J, Kratzke R, Bitterman PB, Wagner CR. 2013. Treatment of breast and lung cancer cells with a N-7 benzyl guanosine monophosphate tryptamine phosphoramidate pronucleotide (4Ei-1) results in chemosensitization to gemcitabine and induced eIF4E proteasomal degradation. Mol Pharm 10: 523-531.

Lin CJ, Cencic R, Mills JR, Robert F, Pelletier J. 2008. c-Myc and eIF4F are components of a feedforward loop that links transcription and translation. Cancer Res 68: 5326-5334.

Lin CJ, Nasr Z, Premsrirut PK, Proco JA Jr, Hippo Y, Lowe SW, Pelletier J. 2012. Targeting synthetic lethal interactions between Myc and the eIF4F complex impedes tumorigenesis. Cell Rep 1: 325-333.

Lindqvist L, Oberer M, Reibarkh M, Cencic R, Bordeleau ME, Vogt E, Marintchev A, Tanaka J, Fagotto F, Altmann $\mathrm{M}$, et al. 2008. Selective pharmacological targeting of a DEAD box RNA helicase. PLoS ONE 3: e1583.

Long K, Boyce M, Lin H, Yuan J, Ma D. 2005. Structureactivity relationship studies of salubrinal lead to its active biotinylated derivative. Bioorg Med Chem Lett 15: 38493852.

Low WK, Dang Y, Schneider-Poetsch T, Shi Z, Choi NS, Merrick WC, Romo D, Liu JO. 2005. Inhibition of eukaryotic translation initiation by the marine natural product pateamine A. Mol Cell 20: 709-722.

Low WK, Dang Y, Bhat S, Romo D, Liu JO. 2007. Substratedependent targeting of eukaryotic translation initiation factor $4 \mathrm{~A}$ by pateamine A: Negation of domain-linker regulation of activity. Chem Biol 14: 715-727.

Low WK, Li J, Zhu M, Kommaraju SS, Shah-Mittal J, Hull K, Liu JO, Romo D. 2014. Second-generation derivatives of the eukaryotic translation initiation inhibitor pateamine A targeting eIF4A as potential anticancer agents. Bioorg Med Chem 22: 116-125.

Lynch M, Fitzgerald C, Johnston KA, Wang S, Schmidt EV. 2004. Activated eIF4E-binding protein slows G1 progression and blocks transformation by c- $m y c$ without inhibiting cell growth. J Biol Chem 279: 3327-3339.

Ma T, Trinh MA, Wexler AJ, Bourbon C, Gatti E, Pierre P, Cavener DR, Klann E. 2013. Suppression of eIF2 $\alpha$ kinases alleviates Alzheimer's disease-related plasticity and memory deficits. Nat Neurosci 16: 1299-1305.

Mahalingam P, Takrouri K, Chen T, Sahoo R, Papadopoulos E, Chen L, Wagner G, Aktas BH, Halperin JA, Chorev M. 2014. Synthesis of rigidified eIF4E/eIF4G inhibitor-1 (4EGI-1) mimetic and their in vitro characterization as inhibitors of protein-protein interaction. J Med Chem 57: 5094-5111.

Malina A, Mills JR, Pelletier J. 2012. Emerging therapeutics targeting mRNA translation. Cold Spring Harb Perspect Biol 4: a012377.

Mallya S, Fitch BA, Lee JS, So L, Janes MR, Fruman DA. 2014. Resistance to mTOR kinase inhibitors in lymphoma cells lacking 4EBP1. PLoS ONE 9: e88865.

Marciniak SJ, Yun CY, Oyadomari S, Novoa I, Zhang Y, Jungreis R, Nagata K, Harding HP, Ron D. 2004. CHOP induces death by promoting protein synthesis and oxida- tion in the stressed endoplasmic reticulum. Genes Dev 18: 3066-3077.

Marcotrigiano J, Gingras AC, Sonenberg N, Burley SK. 1997. Cocrystal structure of the messenger RNA 5 ' cap-binding protein (eIF4E) bound to 7-methyl-GDP. Cell 89: 951961.

Marcotrigiano J, Gingras AC, Sonenberg N, Burley SK. 1999. Cap-dependent translation initiation in eukaryotes is regulated by a molecular mimic of eIF4G. Mol Cell 3: 707-716.

Mazroui R, Sukarieh R, Bordeleau ME, Kaufman RJ, Northcote P, Tanaka J, Gallouzi I, Pelletier J. 2006. Inhibition of ribosome recruitment induces stress granule formation independently of eukaryotic initiation factor $2 \alpha$ phosphorylation. Mol Biol Cell 17: 4212-4219.

McDonald ER III, de Weck A, Schlabach MR, Billy E, Mavrakis KJ, Hoffman GR, Belur D, Castelletti D, Frias E, Gampa K, et al. 2017. Project DRIVE: A compendium of cancer dependencies and synthetic lethal relationships uncovered by large-scale, deep RNAi screening. Cell 170: 577-592 e510.

McMahon R, Zaborowska I, Walsh D. 2011. Noncytotoxic inhibition of viral infection through eIF4F-independent suppression of translation by 4EGi-1. J Virol 85: 853-864.

Meric F, Hunt KK. 2003. Translation initiation in cancer: A novel target for therapy. Mol Canc Ther 1: 971-979.

* Merrick WC, Pavitt GD. 2018. Protein synthesis initiation in eukaryotic cells. Cold Spring Harb Perspect Biol doi: 10.1101/cshperspect.a033092.

Mills JR, Hippo Y, Robert F, Chen SM, Malina A, Lin CJ, Trojahn U, Wendel HG, Charest A, Bronson RT, et al. 2008. mTORC1 promotes survival through translational control of Mcl-1. Proc Natl Acad Sci 105: 10853-10858.

Moerke NJ, Aktas H, Chen H, Cantel S, Reibarkh MY, Fahmy A, Gross JD, Degterev A, Yuan J, Chorev M, et al. 2007. Small-molecule inhibition of the interaction between the translation initiation factors eIF4E and eIF4G. Cell 128: 257-267.

Niedzwiecka A, Marcotrigiano J, Stepinski J, JankowskaAnyszka M, Wyslouch-Cieszynska A, Dadlez M, Gingras AC, Mak P, Darzynkiewicz E, Sonenberg N, et al. 2002. Biophysical studies of eIF4E cap-binding protein: Recognition of mRNA $5^{\prime}$ cap structure and synthetic fragments of eIF4G and 4E-BP1 proteins. J Mol Biol 319: 615-635.

Nielsen PJ, Trachsel H. 1988. The mouse protein synthesis initiation factor $4 \mathrm{~A}$ gene family includes two related functional genes which are differentially expressed. $E M B O J$ 7: 2097-2105.

Northcote PT, Blunt JW, Munro MHG. 1991. Pateamine-A potent cytotoxin from the New Zealand marine sponge, Mycale sp. Tetrahedron Lett 32: 6411-6414.

Novoa I, Zeng H, Harding HP, Ron D. 2001. Feedback inhibition of the unfolded protein response by GADD34mediated dephosphorylation of eIF2 $\alpha$. J Cell Biol 153: 1011-1022.

Papadopoulos E, Jenni S, Kabha E, Takrouri KJ, Yi T, Salvi N, Luna RE, Gavathiotis E, Mahalingam P, Arthanari H, et al. 2014. Structure of the eukaryotic translation initiation factor eIF4E in complex with 4EGI-1 reveals an allosteric mechanism for dissociating eIF4G. Proc Natl Acad Sci 111: E3187-E3195. 
J. Chu and J. Pelletier

Pause A, Belsham GJ, Gingras AC, Donzé O, Lin TA, Lawrence JC Jr, Sonenberg N. 1994. Insulin-dependent stimulation of protein synthesis by phosphorylation of a regulator of 5'-cap function. Nature 371: 762-767.

Pelletier J, Peltz SW. 2007. Therapeutic opportunities in translation, pp. 855-895. Cold Spring Harbor Laboratory Press, New York.

Pelletier J, Graff J, Ruggero D, Sonenberg N. 2015. Targeting the eIF4F translation initiation complex: A critical nexus for cancer development. Cancer Res 75: 250-263.

Pestka S. 1977. Inhibitors of protein synthesis. Academic, New York

Petroulakis E, Parsyan A, Dowling RJ, LeBacquer O, Martineau Y, Bidinosti M, Larsson O, Alain T, Rong L, Mamane $\mathrm{Y}$, et al. 2009. p53-dependent translational control of senescence and transformation via $4 \mathrm{E}-\mathrm{BPs}$. Cancer Cell 16: 439-446.

Pyronnet S, Imataka H, Gingras AC, Fukunaga R, Hunter T, Sonenberg N. 1999. Human eukaryotic translation initiation factor $4 \mathrm{G}$ (eIF4G) recruits mnk1 to phosphorylate eIF4E. EMBO J 18: 270-279.

Radtke K, English L, Rondeau C, Leib D, Lippé R, Desjardins M. 2013. Inhibition of the host translation shutoff response by herpes simplex virus 1 triggers nuclear envelope-derived autophagy. J Virol 87: 3990-3997.

Ran I, Laplante I, Bourgeois C, Pépin J, Lacaille P, CostaMattioli M, Pelletier J, Sonenberg N, Lacaille JC. 2009. Persistent transcription- and translation-dependent long-term potentiation induced by mGluR1 in hippocampal interneurons. J Neurosci 29: 5605-5615.

Raught B, Peiretti F, Gingras AC, Livingstone M, Shahbazian D, Mayeur GL, Polakiewicz RD, Sonenberg N, Hershey JW. 2004. Phosphorylation of eucaryotic translation initiation factor $4 \mathrm{~B}$ Ser422 is modulated by S6 kinases. EMBO J 23: 1761-1769.

Ravindar K, Reddy MS, Lindqvist L, Pelletier J, Deslongchamps P. 2010. Efficient synthetic approach to potent antiproliferative agent hippuristanol via $\mathrm{Hg}$ (II)-catalyzed spiroketalization. Org Lett 12: 4420-4423.

Ravindar K, Reddy MS, Lindqvist L, Pelletier J, Deslongchamps P. 2011. Synthesis of the antiproliferative agent hippuristanol and its analogues via Suárez cyclizations and $\mathrm{Hg}(\mathrm{II})$-catalyzed spiroketalizations. J Org Chem 76: 1269-1284.

Reijonen S, Putkonen N, Norremolle A, Lindholm D, Korhonen L. 2008. Inhibition of endoplasmic reticulum stress counteracts neuronal cell death and protein aggregation caused by $\mathrm{N}$-terminal mutant huntingtin proteins. Exp Cell Res 314: 950-960.

Rinker-Schaeffer CW, Graff JR, De Benedetti A, Zimmer SG, Rhoads RE. 1993. Decreasing the level of translation initiation factor $4 \mathrm{E}$ with antisense RNA causes reversal of ras-mediated transformation and tumorigenesis of cloned rat embryo fibroblasts. Int J Cancer 55: 841-847.

Robert F, Pelletier J. 2009. Translation initiation: A critical signalling node in cancer. Expert Opin Ther Targets 13. 1279-1293.

Robert F, Kapp LD, Khan SN, Acker MG, Kolitz S, Kazemi S, Kaufman RJ, Merrick WC, Koromilas AE, Lorsch JR, et al. 2006. Initiation of protein synthesis by hepatitis $C$ virus is refractory to reduced eIF2.GTP.Met-tRNAiMet ternary complex availability. Mol Biol Cell 17: 4632-4644.
Robert F, Carrier M, Rawe S, Chen S, Lowe S, Pelletier J. 2009a. Altering chemosensitivity by modulating translation elongation. PLOS ONE 4: e5428.

Robert F, Williams C, Yan Y, Donohue E, Cencic R, Burley SK, Pelletier J. 2009b. Blocking UV-induced eIF2 $\alpha$ phosphorylation with small molecule inhibitors of GCN2. Chem Biol Drug Des 74: 57-67.

Robert F, Roman W, Bramoullé A, Fellmann C, Roulston A, Shustik C, Porco JA Jr, Shore GC, Sebag M, Pelletier J. 2014. Translation initiation factor eIF4F modifies the dexamethasone response in multiple myeloma. Proc Natl Acad Sci 111: 13421-13426.

Robichaud N, del Rincon SV, Huor B, Alain T, Petruccelli LA, Hearnden J, Goncalves C, Grotegut S, Spruck CH, Furic L, et al. 2015. Phosphorylation of eIF4E promotes EMT and metastasis via translational control of SNAIL and MMP-3. Oncogene 34: 2032-2042.

Rojas-Rivera D, Delvaeye T, Roelandt R, Nerinckx W, Augustyns K, Vandenabeele P, Bertrand MJM. 2017. When PERK inhibitors turn out to be new potent RIPK1 inhibitors: Critical issues on the specificity and use of GSK2606414 and GSK2656157. Cell Death Differ 24: $1100-1110$

Romo D, Choi NS, Li S, Buchler I, Shi Z, Liu JO. 2004. Evidence for separate binding and scaffolding domains in the immunosuppressive and antitumor marine natural product, pateamine A: Design, synthesis, and activity studies leading to a potent simplified derivative. $J \mathrm{Am}$ Chem Soc 126: 10582-10588.

Rosenwald IB, Rhoads DB, Callanan LD, Isselbacher KJ, Schmidt EV. 1993. Increased expression of eukaryotic translation initiation factors eIF-4E and eIF- $2 \alpha$ in response to growth induction by c-myc. Proc Natl Acad Sci 90: 6175-6178.

Rousseau D, Gingras AC, Pause A, Sonenberg N. 1996. The eIF4E-binding proteins 1 and 2 are negative regulators of cell growth. Oncogene 13: 2415-2420.

Roy B, Vaughn JN, Kim BH, Zhou F, Gilchrist MA, Von Arnim AG. 2010. The h subunit of eIF3 promotes reinitiation competence during translation of mRNAs harboring upstream open reading frames. RNA 16: 748-761.

Rubio CA, Weisburd B, Holderfield M, Arias C, Fang E, DeRisi JL, Fanidi A. 2014. Transcriptome-wide characterization of the eIF4A signature highlights plasticity in translation regulation. Genome Biol 15: 476.

Santini E, Huynh TN, MacAskill AF, Carter AG, Pierre P, Ruggero D, Kaphzan H, Klann E. 2013. Exaggerated translation causes synaptic and behavioural aberrations associated with autism. Nature 493: 411-415.

Saxena S, Cabuy E, Caroni P. 2009. A role for motoneuron subtype-selective ER stress in disease manifestations of FALS mice. Nat Neurosci 12: 627-636.

Schewe DM, Aguirre-Ghiso JA. 2009. Inhibition of eIF2 $\alpha$ dephosphorylation maximizes bortezomib efficiency and eliminates quiescent multiple myeloma cells surviving proteasome inhibitor therapy. Cancer Res 69: 1545-1552.

Sekine Y, Zyryanova A, Crespillo-Casado A, Fischer PM, Harding HP, Ron D. 2015. Stress responses. Mutations in a translation initiation factor identify the target of a memory-enhancing compound. Science 348: 1027-1030.

Sendoel A, Dunn JG, Rodriguez EH, Naik S, Gomez NC, Hurwitz B, Levorse J, Dill BD, Schramek D, Molina H, 
et al. 2017. Translation from unconventional $5^{\prime}$ start sites drives tumour initiation. Nature 541: 494-499.

Shan Y, Wang C, Zhang L, Wang J, Wang M, Dong Y. 2016. Expanding the structural diversity of diarylureas as multitarget tyrosine kinase inhibitors. Bioorg Med Chem 24: 750-758.

Shuda M, Velásquez C, Cheng E, Cordek DG, Kwun HJ, Chang Y, Moore PS. 2015. CDK1 substitutes for mTOR kinase to activate mitotic cap-dependent protein translation. Proc Natl Acad Sci 112: 5875-5882.

Sidrauski C, Acosta-Alvear D, Khoutorsky A, Vedantham P, Hearn BR, Li H, Gamache K, Gallagher CM, Ang KK, Wilson C, et al. 2012. Pharmacological brake-release of mRNA translation enhances cognitive memory. eLife 2: e00498.

Sidrauski C, Tsai JC, Kampmann M, Hearn BR, Vedantham P, Jaishankar P, Sokabe M, Mendez AS, Newton BW, Tang EL, et al. 2015a. Pharmacological dimerization and activation of the exchange factor eIF2B antagonizes the integrated stress response. eLife 4: $\mathrm{e} 07314$.

Sidrauski C, McGeachy AM, Ingolia NT, Walter P. 2015b. The small molecule ISRIB reverses the effects of eIF 20 phosphorylation on translation and stress granule assembly. eLife 4: e05033.

Silvera D, Formenti SC, Schneider RJ. 2010. Translational control in cancer. Nat Rev Cancer 10: 254-266.

Smith WW, Jiang H, Pei Z, Tanaka Y, Morita H, Sawa A, Dawson VL, Dawson TM, Ross CA. 2005. Endoplasmic reticulum stress and mitochondrial cell death pathways mediate A53T mutant $\alpha$-synuclein-induced toxicity. Hum Mol Genet 14: 3801-3811.

Smith KA, Zhou B, Avdulov S, Benyumov A, Peterson M, Liu Y, Okon A, Hergert P, Braziunas J, Wagner CR, et al. 2015. Transforming growth factor- $\beta 1$ induced epithelial mesenchymal transition is blocked by a chemical antagonist of translation factor eIF4E. Sci Rep 5: 18233.

Somaiah R, Ravindar K, Cencic R, Pelletier J, Deslongchamp P. 2014. Synthesis of the antiproliferative agent hippuristanol and its analogues from hydrocortisone via $\mathrm{Hg}(\mathrm{II})$ catalyzed spiroketalization: Structure-activity relationship. J Med Chem 57: 2511-2523.

Stumpf CR, Ruggero D. 2011. The cancerous translation apparatus. Curr Opin Genet Dev 21: 474-483.

Tamburini J, Green AS, Bardet V, Chapuis N, Park S, Willems L, Uzunov M, Ifrah N, Dreyfus F, Lacombe C, et al. 2009. Protein synthesis is resistant to rapamycin and constitutes a promising therapeutic target in acute myeloid leukemia. Blood 114: 1618-1627.

Terenin IM, Dmitriev SE, Andreev DE, Shatsky IN. 2008 Eukaryotic translation initiation machinery can operate in a bacterial-like mode without eIF2. Nat Struct Mol Biol 15: 836-841.

Thumma SC, Jacobson BA, Patel MR, Konicek BW, Franklin MJ, Jay-Dixon J, Sadiq A, De A, Graff JR, Kratzke RA. 2015. Antisense oligonucleotide targeting eukaryotic translation initiation factor $4 \mathrm{E}$ reduces growth and enhances chemosensitivity of non-small-cell lung cancer cells. Cancer Gene Ther 22: 396-401.

Tomoo K, Shen X, Okabe K, Nozoe Y, Fukuhara S, Morino S, Ishida $\mathrm{T}$, Taniguchi $\mathrm{T}$, Hasegawa $\mathrm{H}$, Terashima $\mathrm{A}$, et al 2002. Crystal structures of 7-methylguanosine $5^{\prime}$-triphosphate (m(7)GTP)- and P(1)-7-methylguanosine- $\mathrm{P}(3)$ - adenosine- $5^{\prime}, 5^{\prime}$-triphosphate (m(7)GpppA)-bound human full-length eukaryotic initiation factor $4 \mathrm{E}$ : Biological importance of the C-terminal flexible region. Biochem J 362: 539-544.

Trinh MA, Klann E. 2013. Translational control by eIF2 $\alpha$ kinases in long-lasting synaptic plasticity and long-term memory. Neurobiol Learn Mem 105: 93-99.

Truitt ML, Conn CS, Shi Z, Pang X, Tokuyasu T, Coady AM, Seo Y, Barna M, Ruggero D. 2015. Differential requirements for eIF4E dose in normal development and cancer. Cell 162: 59-71.

Tsaytler P, Harding HP, Ron D, Bertolotti A. 2011. Selective inhibition of a regulatory subunit of protein phosphatase 1 restores proteostasis. Science 332: 91-94.

Tsumuraya T, Ishikawa C, Machijima Y, Nakachi S, Senba M, Tanaka J, Mori N. 2011. Effects of hippuristanol, an inhibitor of eIF4A, on adult T-cell leukemia. Biochem Pharmacol 81: 713-722.

Vazquez D. 1979. Inhibitors of protein biosynthesis. Mol Biol Biochem Biophys 30: 1-312.

Wagner CR, Iyer VV, McIntee EJ. 2000. Pronucleotides: Toward the in vivo delivery of antiviral and anticancer nucleotides. Med Res Rev 20: 417-451.

Wang H, Blais J, Ron D, Cardozo T. 2010. Structural determinants of PERK inhibitor potency and selectivity. Chem Biol Drug Des 76: 480-495.

Waskiewicz AJ, Johnson JC, Penn B, Mahalingam M, Kimball SR, Cooper JA. 1999. Phosphorylation of the capbinding protein eukaryotic translation initiation factor 4E by protein kinase Mnk1 in vivo. Mol Cell Biol 19: 1871-1880.

* Wek RC. 2018. Role of elF2 $\alpha$ kinases in translational control and adaptation to cellular stresses. Cold Spring Harb Perspect Biol doi: 10.1101/cshperspect.a032870.

Wendel HG, De Stanchina E, Fridman JS, Malina A, Ray S, Kogan S, Coron-Cardo C, Pelletier J, Lowe SW. 2004. Survival signalling by Akt and eIF4E in oncogenesis and cancer therapy. Nature 428: 332-337.

Williams JG, Penman S. 1975. The messenger RNA sequences in growing and resting mouse fibroblasts. Cell 6: 197-206.

Wolfe AL, Singh K, Zhong Y, Drewe P, Rajasekhar VK, Sanghvi VR, Mavrakis KJ, Jiang M, Roderick JE, Van der Meulen J, et al. 2014. RNA G-quadruplexes cause eIF4A-dependent oncogene translation in cancer. Nature 513: 65-70.

Wu M, Zhang C, Li XJ, Liu Q, Wanggou S. 2016. Anti-cancer effect of cap-translation inhibitor 4EGI-1 in human glioma U87 cells: Involvement of mitochondrial dysfunction and ER stress. Cell Physiol Biochem 40: 1013-1028.

Yan GR, Xiao CL, He GW, Yin XF, Chen NP, Cao Y, He QY. 2010. Global phosphoproteomic effects of natural tyrosine kinase inhibitor, genistein, on signaling pathways. Proteomics 10: $976-986$.

Yang HS, Jansen AP, Komar AA, Zheng X, Merrick WC, Costes S, Lockett SJ, Sonenberg N, Colburn NH. 2003a. The transformation suppressor Pdcd4 is a novel eukaryotic translation initiation factor $4 \mathrm{~A}$ binding protein that inhibits translation. Mol Cell Biol 23: 26-37. 
J. Chu and J. Pelletier

Yang HS, Knies JL, Stark C, Colburn NH. 2003b. Pdcd4 suppresses tumor phenotype in JB6 cells by inhibiting AP-1 transactivation. Oncogene 22: 3712-3720.

Yang X, Dong QF, Li LW, Huo JL, Li PQ, Fei Z, Zhen HN 2015. The cap-translation inhibitor 4EGI-1 induces mitochondrial dysfunction via regulation of mitochondrial dynamic proteins in human glioma U251 cells. Neurochem Int 90: 98-106.

Yángüez E, Castello A, Welnowska E, Carrasco L, Goodfellow I, Nieto A. 2011. Functional impairment of eIF4A and eIF4G factors correlates with inhibition of influenza virus mRNA translation. Virology 413: 93-102.

Yi T, Papadopoulos E, Hagner PR, Wagner G. 2013. Hypoxia-inducible factor- $1 \alpha$ (HIF-1 $\alpha)$ promotes capdependent translation of selective mRNAs through upregulating initiation factor eIF4E1 in breast cancer cells under hypoxia conditions. J Biol Chem 288: 18732 18742.

Zhang L, Pan X, Hershey JW. 2007. Individual overexpression of five subunits of human translation initiation factor eIF3 promotes malignant transformation of immortal fibroblast cells. J Biol Chem 282: 5790-5800.

Zhou FF, Yan M, Guo GF, Wang F, Qiu HJ, Zheng FM, Zhang Y, Liu Q, Zhu XF, Xia LP. 2011. Knockdown of eIF4E suppresses cell growth and migration, enhances chemosensitivity and correlates with increase in Bax/ Bcl-2 ratio in triple-negative breast cancer cells. Med Oncol 28: 1302-1307.

Zindy P, Bergé Y, Allal B, Filleron T, Pierredon S, Cammas A Beck S, Mhamdi L, Fan L, Favre G, et al. 2011. Formation of the eIF4F translation-initiation complex determines sensitivity to anticancer drugs targeting the EGFR and HER2 receptors. Cancer Res 71: 4068-4073. 


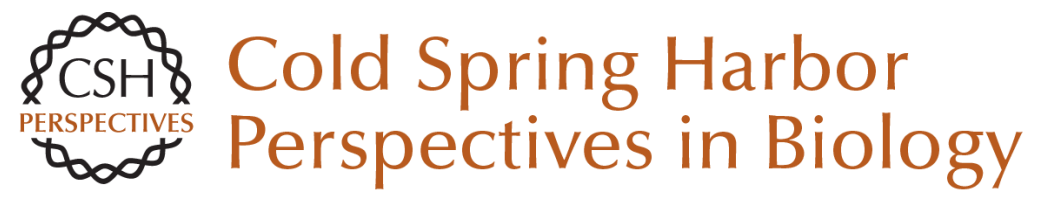

\section{Therapeutic Opportunities in Eukaryotic Translation}

Jennifer Chu and Jerry Pelletier

Cold Spring Harb Perspect Biol 2018; doi: 10.1101/cshperspect.a032995 originally published online February 12, 2018

\section{Subject Collection Translation Mechanisms and Control}

Protein Synthesis and Translational Control: A Historical Perspective

Soroush Tahmasebi, Nahum Sonenberg, John W.B. Hershey, et al.

Translational Control in the Brain in Health and Disease

Wayne S. Sossin and Mauro Costa-Mattioli

Phosphorylation and Signal Transduction

Pathways in Translational Control Christopher G. Proud

Translational Control during Developmental Transitions

Felipe Karam Teixeira and Ruth Lehmann

Stress Granules and Processing Bodies in

Translational Control

Pavel Ivanov, Nancy Kedersha and Paul Anderson

Fluorescence Imaging Methods to Investigate

Translation in Single Cells

Jeetayu Biswas, Yang Liu, Robert H. Singer, et al.

Translational Control in Virus-Infected Cells Noam Stern-Ginossar, Sunnie R. Thompson, Michael B. Mathews, et al.

Nonsense-Mediated mRNA Decay Begins Where

Translation Ends

Evangelos D. Karousis and Oliver Mühlemann
Principles of Translational Control John W.B. Hershey, Nahum Sonenberg and Michael B. Mathews

The Epitranscriptome in Translation Regulation Eyal Peer, Sharon Moshitch-Moshkovitz, Gideon Rechavi, et al.

Translational Control in Cancer Nathaniel Robichaud, Nahum Sonenberg, Davide Ruggero, et al.

Roles of Long Noncoding RNAs and Circular

RNAs in Translation Marina Chekulaeva and Nikolaus Rajewsky

Ribosome Profiling: Global Views of Translation Nicholas T. Ingolia, Jeffrey A. Hussmann and Jonathan S. Weissman

Noncanonical Translation Initiation in Eukaryotes Thaddaeus Kwan and Sunnie R. Thompson

Mechanistic Insights into MicroRNA-Mediated Gene Silencing Thomas F. Duchaine and Marc R. Fabian

Toward a Kinetic Understanding of Eukaryotic Translation Masaaki Sokabe and Christopher S. Fraser

For additional articles in this collection, see http://cshperspectives.cshlp.org/cgi/collection/

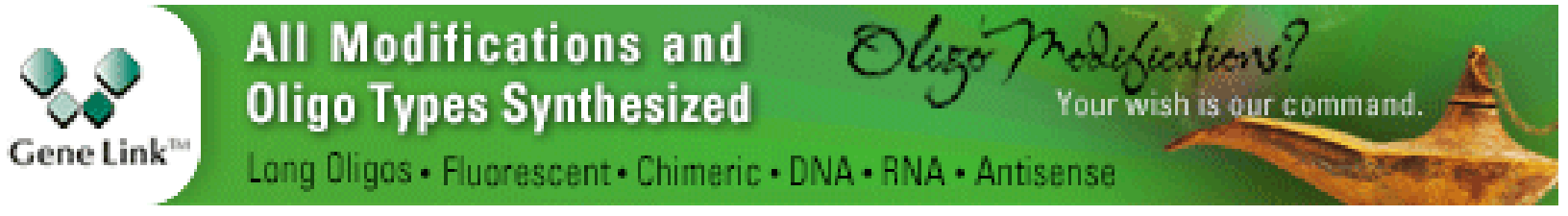

